
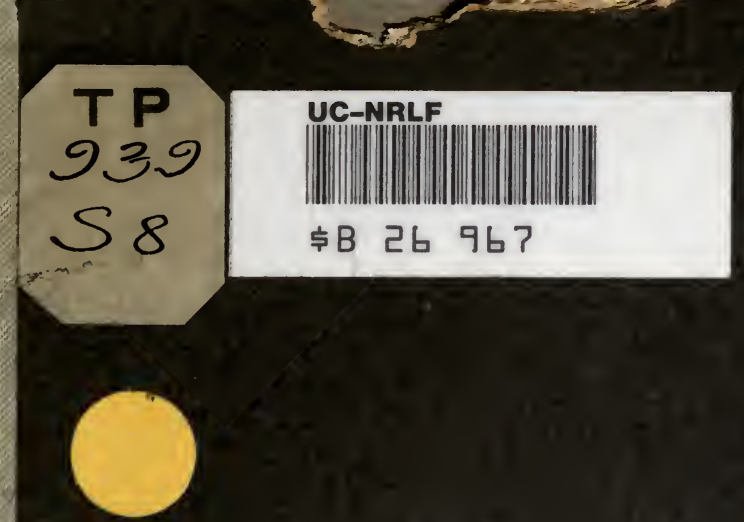

N

in

m 


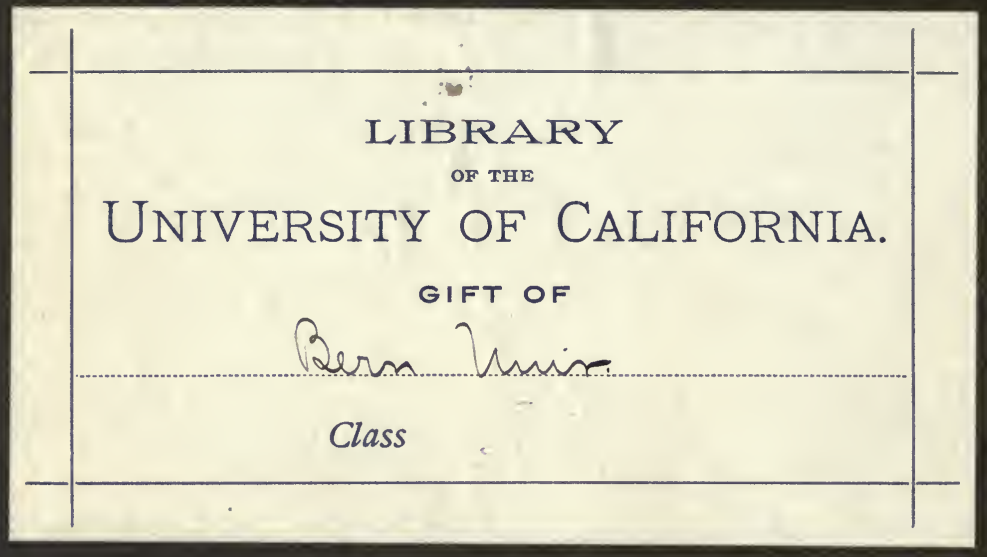


Juำ 101507

\title{
Japanese Lac-Ki-urushi
}

\author{
ALVISO B. STEVENS
}





\title{
Contribution to the Knowledge of
} Japanese Lac

(Ki-urushi)

\section{THESIS}

Presented to the Philosophical Faculty of the University of Bern, for the Degree of Doctor of Philosophy.

\author{
By ALVISO B. STEVENS \\ University of Michigan \\ Ann Arbor, Michigan, United States of America
}

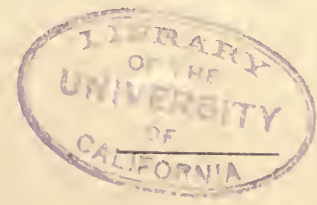

ANN ARBOR:

The Ann Arbor Press, Printers

1906 



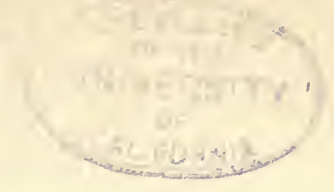

\section{JAPANESE LAC (KI-URUSHI)}

Doubtless nearly every one has seen and admired the beautiful Japanese vases or boxes without realizing that they were finished with the most indestructible varnish known to man. There are at present vases, more than a century old, that have retained their beautiful luster so perfectly that they look as though they had been finished but yesterday. The hardened surface formed by the genuine Japanese lac, is practically unaffected by the usual reagents, which are so detrimental to most varnished surfaces, as, alcohol, ether, alkalies and acids. It is acted upon to some extent by strong sulphuric or nitric acicls, and may be dissolved by continued heating in fuming nitric acid.

Rein ${ }^{1}$ states that the Japanese doubtless received their knowledge of the lac industry from the Chinese in the early part of the third century; but that its use did not attain great importance before the middle of the seventh century. Kôtoku-Tennô, the 36 Mikado (645 to 654 A. D.) had a ceremonial head covering of paper, which was covered with black lacquer. There is a lacquered scarf box in the temple at Nara, which belonged to a priest in the time of Kinnari Tenno '( 540 to 572 A. D.).

For centuries its use and production remained a secret. As late as 1873 we find the statement that "The manner of preparing the varnish and the mode of applying it, is likely to remain a secret." In the following year Prof. J. J. Rein made a thor-

1 J. J. Rein's The Industries of Japan, London, 1889, Lacquer Work, pp. 339-377; Rein, Japan II, Leipzig 1886. This Author has minutely described the lac industry and it is to his excellent work that I shall frequently refer.

${ }^{2}$ Belfour's Cyclopædia of India. 
ough study of the method of collecting and applying the lac. $\mathrm{He}$ describes the tree, Rhus vernicifera, from which the lac is obtained, as follows:

"Lacquer trees grow up straight and have fairly symmetrical crowns. The young trees have fine, large, pinnate leaves, which in good soil often grow to be more than a meter long, and far exceed all other species of Rhus in size and beauty. The leaves are unequally pinnate and have long stems. Before falling off in October they become yellow or reddish brown. There are from nine to fifteen leaflets, large, oval, pointed and unindented, which have fine short hairs on the under side.

"In June appear loose, greenish yellow branches of blossoms, from numerous axils near the end of the thick twigs. The fruit is ripe in the second half of October, is yellowish green and remains hanging all winter, though usually gathered in November.

"The two sexes are separate. Therefore when the chief object of its cultivation is the manufacture of wax from the seed, the male trees should be avoided, reproduction being obtained by root sprouts from female specimens. The trees begin to bear fruit when eight years old and increase in productiveness until thirty or forty yeats old."

Shirasawa gives the following: $:^{3}$ Rhus vernicifera, D. C., Syn. Jap. Urushi-no-ki, Fam. Anacardiaceæ.

"Cultivated in the countries of the temperate zone, i. e. Shinono, Kai, etc., and the provinces to the northeast of Honshiu. It does not grow in warm regions, and thrives best in moist soil. The tree attains its growth quickly and reaches a hight of ro meters, and the trunk a diameter of four decimeters.

"The buds are of a pyramidal form, short with curved points and covered with hairs of a brown, ash-gray color and glistening; cicatrix of the leaves large, heart shaped; pith large.

"Flowers, end of May; fruit, end of October.

"The wood is soft and brittle, with a remarkable difference in the color between the sap wood, which is white and the heart

'Iconographie des Essences forestieres du Japan.' par, M. Homi Shirasawa, 1899, p. 94. 
wood which is yellow. Air dried $0.5 \mathrm{I}$ sp. gr., kiln dried 0.45 sp. gr.

"The wood is used for the manufacture of utensils, furniture, bric-a-brac, wood engraving, etc.

"The lac is gathered in China, of which the provinces Noto, Iwashivo are renowned. Wax is collected from the fruit."

Doubtless the principal source of vegetable wax is Rhus succedanea and R. sylvestris. The former is cultivated extensively in the warmer parts of Japan, south of latitude $35^{\circ} \mathrm{N}$. Japan but is cultivated principally between latitudes $35^{\circ}$ and $39^{\circ}$,

The lacquer-tree grows in nearly all parts of China and including the provinces of Etschizin, Schinano, Aidzo, Yoshino and Yamato. The greatest yield is from trees 15 to 20 years old, but the age of the trees when the lac is collected varies in different localities, in some places at from five to six years old when the stem is the size of a man's arm and in other localities at from nine to ten years old. The time of collecting is from April or May to the first of November.

The tree and its anatomic relations are given in detail by Moebius4. He states that schizogenic lacticiferous canals are present in all parts of the plant. These contain the milk juice that exucles after incision.

\section{METHOD OF COLLECTING THE LAC, AND ITS PROPERTIES.}

The peasants sell the trees to the lac merchants who employ collectors to gather the lac. Each workman operates upon from 600 to 800 old trees, or 1000 young trees in a season. He begins at the bottom of the tree and makes horizontal incisions through the

- Der Japanishe Lacbaum, Rhus vernicifera D. C. Eine Morphiologishe anatomische Studie aphandlungen der senkenbergischen naturforschenden Gasellschaft, Band XX, Heft II.

The principal facts have been taken from Rein's Industries of Japan, but reference is also made to "Japanischer Lack" by Dr. Wagner, Dingler's polyt. Journal, 218, 1875, pp. 36I-367.

The above description is nearly the same as that given by Ishimatsu, which he states was partly taken from an account of the urushi manufacture published for the use of the Japanese primary schools. Manchester Literary and Philosophical Soc. 3 series, 7, 1882, p. 449. 
bark about six millimeters wide ${ }^{6}$ with the sharp side of the Kakigama, a hook shaped instrument (No. Io, p. Io). He then repeats the operation on the other side of the tree about $\mathrm{I}_{5}$ or $20 \mathrm{c.m}$. higher. Thus alternating from side to side until he has cut as high as he can reach, making from six to ten grooves on a side, which extend about half way round the tree. He then goes to other trees until about ten or fifteen trees have been cut after which he returns to the first trees and collects the raw lac. This is removed with the Natsu-bera, an iron spatula with a curved point (No. II, p. Io), and scraped into the Gô, a small wooden or bamboo pail, which the workman carries in his left hand. After about four days he returns to the first group of trees and cuts grooves parallel to each of the first. These operations are repeated at intervals until the tree is literally covered with grooves. The entire operation requires from 60 to Ioo days.

The juice usually fills, but does not flow out of the grooves. In the spring the lac is thin, gradually becoming thicker as the season advances. The best is collected in mid-summer. When collected the juice is in the form of a thick grayish-white emulsion, which on exposure to air rapidly changes to brown and finally to black. If left in an open can it rapidly forms a black skin over the surface which prevents further oxidation. The lac collected as above is the best quality, known as "Ki-Urushi" and has a sp. gr. of 1.002 to 1.0379 . When strongly magnified it appears to be a brownish mass of globules, which consists of two kinds, one kind small, dark brown and between these a less number of large, light-colored globules, the former soluble in alcohol and the latter in water. A second grade known as "Seshime-Urushi" is obtained at the close of the season by cutting down some of the trees and cutting and binding the branches into bundles about one metre long and these with the trunk are macerated in warm water when the sap comes to the surface and is removed. Wagner ${ }^{7}$ states that after maceration the branches are placed in a screw press to remove the juice. This is thin and dark and, after mixing with some drying oil, is used as an under varnish. Each tree yields on an average from 27 to 54 Grammes

- Rein gives $2 \mathrm{~m} . \mathrm{m}$. wide, but Wagner gives $6 \mathrm{~m} . \mathrm{m}$. Doubtless the latter is more nearly correct.

'Dingler's Polytechnisches Jour. 2I8, p. 36I-I875. 


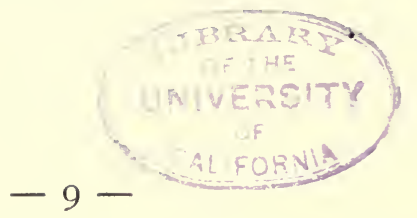

of raw lac. In China the yield is said to be much less, in some districts not more than Io Grammes.

Yoshida $^{8}$ states that Ki-Urushi is never sent to the market in the form in which it is obtained from the tree but is usually mixed with about $40 \%$ of "Mokuyiki" (wood juice) which closely resembles $\mathrm{Ki}$-Urushi but contains a much larger proportion of gum and about $1 / 4$ as much substance soluble in alcohol. It is doubtless an impure form of urushi juice. Before the raw lac is ready for use it must be strained through cot:on or linen cloth to remove pieces of bark and foreign particles. It is then stirred in a shallow wooden pail to remove the grain and give it a uniform consistence. The varnish makers sometimes add linseed oil : also from I-IO\% of perilla oil is sometimes added. The lac mixed with $\mathrm{I} / 5$ perilla oil is sometimes used for coating umbrellas and water proofs. Various colors are made by adding pigments. The red, so frequently used for a part of Japanese decorations is formed by mixing 70 parts Ki-Urushi, 20 parts linseed oil and to parts vermillion. One per cent of gamboge either in powder or in solution is sometimes addled. The best gloss black is formed by mixing purified lac with acetate of iron, formed by macerating nails or iron filings in vinegar or rice beer, and heating or exposing to the action of the sun. The lac thus prepared contains from 0.5 to $2 \%$ of iron. Other substances are sometimes added as indigo, iron oxide, lead oxide, charcoal, and for decorative purposes, gold and silver dust, gold, silver, and tin foil are used.

The only substance used by the Japanese to thin the lac is camphor, which is powdered and mixed with the lac. Rein observed that when water is mixed with lac that it thickens and becomes jelly-like, and if applied to wood dries very rapidly.

If the lac is allowed to harden in a dry atmosphere it has a dull appearance. Hence it must be dried in the presence of moisture which is necessary to ensure the best action of the enzyme. Therefore the articles coated with the lac are placed in a room and wet cloths are hung on the wall or about the lacquered articles. A temperature of from $20^{\circ}$ to $30^{\circ}$ is best adapted for this process.

${ }^{8}$ Jour. Chem. Soc., 1883-p. 472.

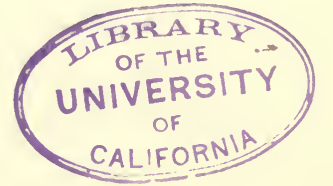




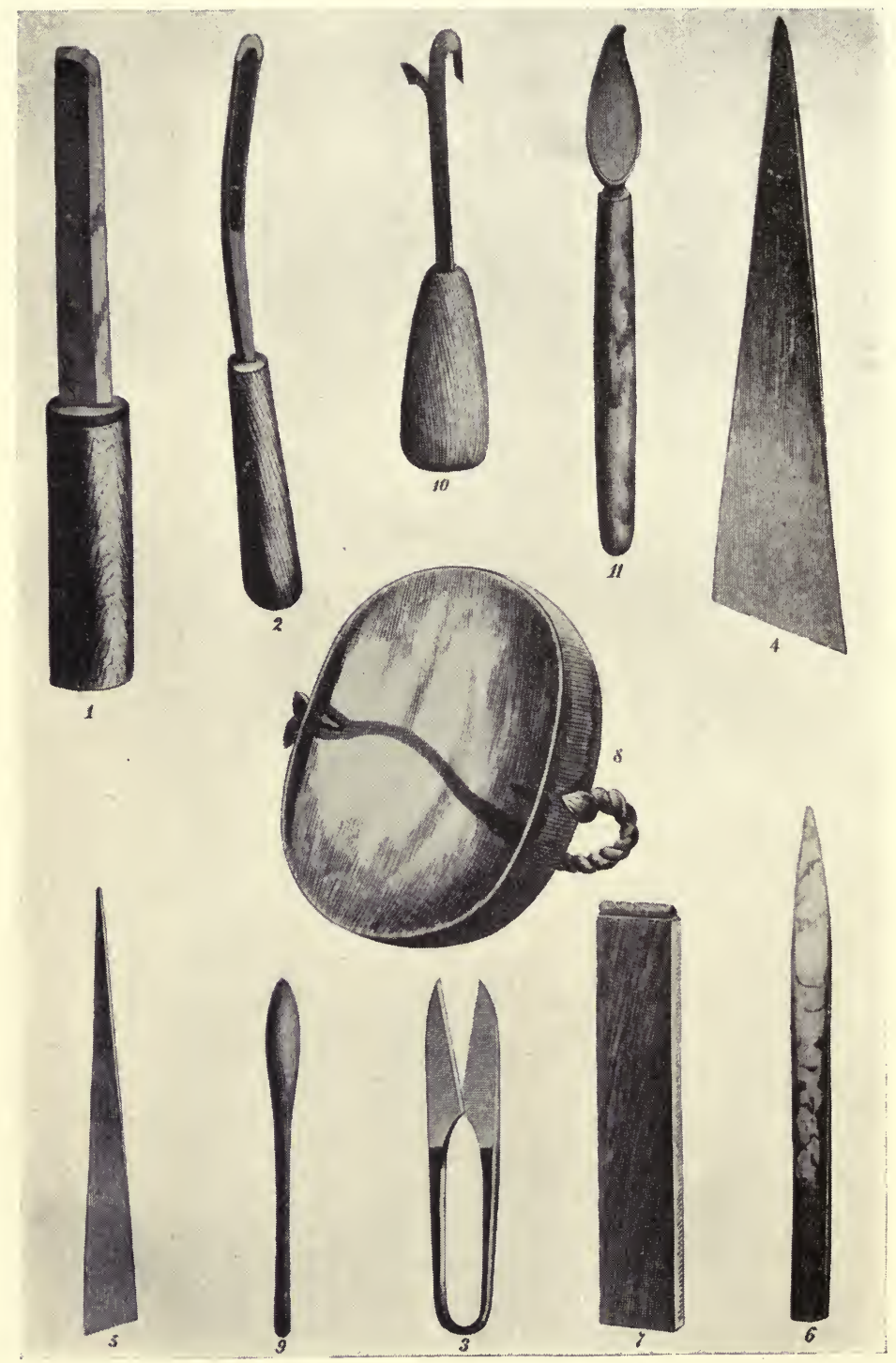

INSTRUMENTS USED IN COLLECTING AND APPLYING THE LAC. 
INSTRUMENTS USED IN COLLECTING AND APPLYING THE LAC.

The accompanying reproduction is from "Rein's Japan," and is from original instruments in the Royal Industrial Art Museum in Berlin.

No. I is a sharp kitchen knife; No. 2, a gouge or chisel; No. 3, shears; Nos. 4 and 5 , wooden spatulas; No. 6, a bambon spatula; No. 7, a surface brush made from human hair; No. 8, palette made of tortoise shell or buffalo horn, to be carried on the hand; No. 9, spoon for putting on the gold or silver dust. The above, with various sized brushes made of deer and rat's hair form the implements used in applying the lac, gold, silver leaf, etc. Nos. Io and II are used in collecting the lac and have already been described.

RUI,ES TO BE, OBSERVED BY THF, WORKMEN.

I. The surface must be brushed over equally, first in one direction and then in the other.

2. The old coat must be thoroughly dried before a new one is applied.

3. The drying is best conducted in vapor of steam.

4. Only the ground coat can be dried in the open air or sun, and that only when the coating contains very little or no lac.

5. The peculiar lac properties result from drying without heat in a chest or closed room with wet cloths placed by the side of the object or on the sides of the room.

6. Dust, light and air are to be excluded while the varnish is hardening.

7. For fine finish the varnish must be strained once or twice through fine porous bast or paper.

8. After every new coat the surface should be polished with charcoal or burnt horn, usually with free application of water.

9. The finished object must not show the quality or the condition of the base-must be free from ridges or specks. The complete mirror must not change by contact with hot water.

Wagner states that the first coat is rubbed down with powdered pumice stone and that the final coat is polished with bone ash and charcoal and finished with the palm of the hand and the tips of the fingers. 
The most important chemical investigations of Japanese lac have been made by three Japanese chemists. Ishimatsu ${ }^{\circ}$ made the first chemical investigation. He states that the lac has a sweetish odor, an irritating taste, burns with a luminous flame emitting dense black smoke and mixes with fixed oils in all proportions; hence these oils are frequently used as adulterants.

$\mathrm{He}$ states that it was generally supposed that the hardening was due to the action of light and air, but he proves that light is practically without effect on the lac, as it is blackened very rapidly when exposed to moist atmosphere during the night or when kept in a light-tight box. It is unacted upon even in sunlight when kept under water, or in carbonic acid in a sealed flask. It dries very slowly in dry air. This he attributes to the rapid drying of the surface, which prevents the evaporation of the volatile constituents, while in moist air the drying takes place so slowly that the volatile constituents have time to escape. This theory is not in harmony with the statement which immediately follows, where he states that the hardening in the atmosphere is, in all probability, due to the oxygen of the air.

He finds that the fresh lac yields $58.24 \%$ of substance soluble in alcohol, while the perfectly dry powdered lac yields only I8.07\% of substance soluble in alcohol. He attributes this difference to the fact that the alcohol has greater difficulty in getting at the dry lac. He fails to realize that the difference is due to a chemical change.

He reports that the lac consists of a substance soluble in alcohol, a gum soluble in hot or cold water, a residue insoluble in alcohol or water, which consists of bark, cellulose, dust, etc. There is also present a small quantity of volatile poison and water.

His method of separation was to extract the lac with absolute alcohol, evaporate the alcohol and dry at $100^{\circ} \mathrm{C}$. to constant weight.

The residue insoluble in alcohol was extracted with hot water, filtered and the filtrate evaporated, dried at $100^{\circ} \mathrm{C}$. and weighed as gum.

- Chemical investigation of Japanese Laquor, or Urushi. Manchester Literary and Philosophical Soc. 3 series, I882, p. 249. Communicated by Professor Roscoe, Read Feb. 18, I879. 
The residue insoluble in water was dried at $100^{\circ} \mathrm{C}$. and weighed.

The water and volatile matter were determined by difference.

Yoshida $^{10}$ used Ishimatsu's method for the separation of the constituents, but reported the part soluble in alcohol as urushic acid, and that soluble in hot water as gum, identical with acacia, and that which was insoluble in water or alcohol as diastatic matter.

He proved that the hardening of the lac was due to the action of an oxidizing enzyme, acting in the presence of moisture. $\mathrm{He}$ states that the enzyme is an albuminous body, coagulated by boiling. In this he is mistaken for the enzyme is intimately associated with the gum and cannot be separated from it, even though it is destroyed by boiling. See under Gum, p. 45 .

Later Korshelt and Yoshicla ${ }^{11}$ examined several samples of lac, using the same method of separation. For comparison the results of these chemists are given in following tabulated form:

\begin{tabular}{|c|c|c|c|c|c|c|c|}
\hline \multirow[b]{2}{*}{$\begin{array}{l}\text { CONSTITUENTS } \\
\text { OF RAW LAC }\end{array}$} & \multirow[b]{2}{*}{ 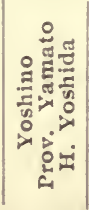 } & \multicolumn{5}{|c|}{ Korschelt and Yoshida } & \multirow[b]{2}{*}{ 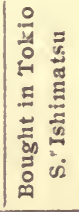 } \\
\hline & & 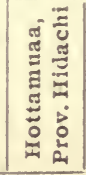 & 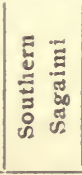 & 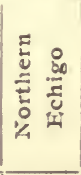 & 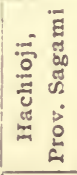 & 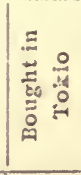 & \\
\hline Lac acid (Urushic acid). & 85.15 & 64.62 & 68.83 & 66.92 & 80.00 & 64.07 & 58.24 \\
\hline Gum $\ldots \ldots \ldots \ldots .$. & 3.15 & $5 \cdot 56$ & 5.02 & 4.75 & 4.69 & 6.05 & 6.32 \\
\hline Nitrogenous residue . & 2.28 & 2.10 & $2.0 \mathrm{I}$ & I. 72 & $3 \cdot 31$ & 3.43 & 2.27 \\
\hline Oil & ? & 0.09 & 0.06 & 0.06 & ? & 0.23 & ? \\
\hline$\ldots \ldots \ldots \ldots \ldots$ & 9.42 & 27.63 & 24.08 & 26.55 & 12.00 & 26.22 & 33.17 \\
\hline
\end{tabular}

It is claimed that the small quantity of oil reported is not a natural constituent, but is due to the oil of Perilla that is used on the knife and spatula to prevent the lac adhering to the iron.

Yoshida states that the Yoshino sample which he analyzed was collected under official inspection for chemical investigation and was evidently pure and that the sample analyzed by Ishimat-

${ }^{10}$ Chemistry of Lacquer, Ki-Urushi. Hikorokuro Yoshida, Jour. Chem. Soc. 1883 , p. 472.

${ }^{i 1}$ Trans. As. Soc. Japan, 12, pp. 182 to 220. 
su must have contained a considerable quantity of Mokuyki, an impure form of urushi juice.

Ishimatsu states that the part soluble in alcohol has the same odor as the original, but never dries up as that does. It is brownish-black, slightly sticky to the touch. With potassium hydroxide it forms a bluish-black precipitate. The alcoholic solution was precipitated by lead acetate. The precipitate was washed, dried and analyzed, with the following results:

\begin{tabular}{|c|c|c|}
\hline & & MEAN \\
\hline C $\ldots \ldots \ldots \ldots .49 .84$ & 51.06 & 50.45 \\
\hline$\ldots \ldots \ldots \ldots \ldots 5.8 \mathrm{I}$ & 5.60 & 5.705 \\
\hline $\mathrm{O} \ldots \ldots \ldots \ldots+40 \cdot 30$ & 39.84 & 40.07 \\
\hline $\mathrm{PbO} \ldots \ldots \ldots \ldots 3.50$ & 4.05 & 3.775 \\
\hline
\end{tabular}

From which he calculated the formula $\mathrm{C}_{20} \mathrm{H}_{30} \mathrm{O}_{2}$.

When he boiled the alcoholic residue with nitric acid it gave off brown fumes and formed an orange colored mass, which when washed was partly soluble in absolute alcohol. This alcoholic solution formed a yellow precipitate with lead acetate or silver nitrate. The lead precipitate explodes when heated. It could not be decomposed by sulphureted hydrogen without decomposition of the acid, therefore he removed the lead by sulphuric acid, and again precipitated with lead acetate, washed, dried the precipitate, and estimated the lead as oxide, and the other constituents by combustion. The results were as follows:

\begin{tabular}{|c|c|c|}
\hline & & MEAN \\
\hline .26 .77 & 27.10 & 26.93 \\
\hline $\mathrm{H} \ldots \ldots \cdots \cdots \cdots \cdot 4.10$ & 4.12 & 4. I I \\
\hline 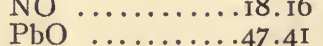 & 18.28 & 18.44 \\
\hline $\mathrm{O} \ldots \ldots \ldots \ldots \ldots m^{4.12}$ & $\begin{array}{r}41.43 \\
3.07\end{array}$ & $\begin{array}{l}4 / .42 \\
3.1\end{array}$ \\
\hline
\end{tabular}

From which he calculated the formula $\mathrm{C}_{11} \mathrm{H}_{20}\left(\mathrm{NO}_{2}\right)_{2} \mathrm{PbO}_{2}$ and for the original substance $\mathrm{C}_{11} \mathrm{H}_{24} \mathrm{O}_{2}$.

The following is an abstract of Yoshida's investigation of the alcohol soluble portion of the lac, which he calls Urushic acid.

It is readily soluble in benzin, ether, carbon disulphide; less easily soluble in fusel oil and petroleum of high boiling point; insoluble in water; sp. gr. $0.985^{\mathrm{I}}$ at $23^{\circ}$. Remains unchanged at $160^{\circ}$. Above $200^{\circ}$ it decomposes slowly with carbonization. From the alcoholic solution many salts can be produced, most of which are slightly soluble in alcohol but insoluble in water. 
With silver nitrate it forms a fine black precipitate moderately soluble in alcohol, which, on boiling is reduced with the formation of a metallic mirror. Platinum chloride, gold chloride, uranium acetate, and copper nitrate form precipitates varying in color from brown to black.

He prepared the lead compound by precipitating with acetate of lead, washing with alcohol and then with boiling water, drying on a water bath and finally over sulphuric acid in an exsiccator. He obtained by analysis the following results:

$\begin{array}{rr}\text { FOUND } & \begin{array}{r}\text { THEORETICAL FOR } \\ \left(\mathrm{C}_{14} \mathrm{H}_{17} \mathrm{O}_{2}\right)_{2} \mathrm{~Pb} .\end{array} \\ \mathrm{C} \ldots \ldots .52 .08 & 52.4 \\ \mathrm{H} \ldots \ldots .54 & 5.3 \\ \mathrm{O} \ldots \ldots .40 .43 & 10.01 \\ \mathrm{~Pb} \ldots \ldots .42 .45 & 32.29\end{array}$

The lead salt is gray; on heating to $100^{\circ}$ it gives off a peculiar odor, turns dark, at $\mathrm{IIO} \mathrm{O}^{\circ}-\mathrm{II} 5^{\circ}$ melts to a brown mass, and at about $120^{\circ}$ ignites spontaneously.

By adding an insufficient quantity of ferric chloride he formed a voluminous black precipitate, which by analysis gave the following formula: $\left(\mathrm{C}_{14} \mathrm{H}_{17} \mathrm{O}_{2}\right)_{3} \mathrm{Fe}+9 \mathrm{C}_{14} \mathrm{H}_{18} \mathrm{O}_{2}$.

By adding a larger proportion of ferric chloride he formed a compound which on analysis gave results corresponding to the following formula: $\left(\mathrm{C}_{14} \mathrm{H}_{17} \mathrm{O}_{2}\right)_{3} \mathrm{Fe}+3 \mathrm{C}_{14} \mathrm{H}_{18} \mathrm{O}_{2}$. Both salts melt to a black mass at $105^{\circ}-110^{\circ}$ and ignite spontaneously at a somewhat higher temperature.

Free alkalies impart a very dark color to the alcoholic solution, which looks purplish-black by transmitted light and dark brown by reflected light. On exposure to air it forms a viscid compound, rapidly becomes black and dries up.

Soluble salts of mercury, zinc, nickel, cobalt, manganese and earthy metals do not give any distinct reaction.

To a solution of the acid in carbon disulphide, bromine was gradually added in excess and the whole evaporated to dryness on a water bath, the mass extracted with strong alcohol, and the extract again evaporated, whereupon it yielded a dark semi-fluid mass. This was examined for bromine by igniting with pure lime. $0.7060 \mathrm{gm}$. gave I.I5I gm. $\mathrm{AgBr}=69.37 \%$ of bromine agreeing very nearly with a hexabromo derivative of the acid, $\mathrm{C}_{14} \mathrm{H}_{12} \mathrm{Br}_{6} \mathrm{O}_{2}$, which requires $69.36 \%$. 
Yoshida subjected his urushic acid to the continued action of hydrochloric acid for three days, and obtained a hard brown mass which he cut into pieces, boiled with water, washed with alcohol, dried at $100^{\circ} \mathrm{C}$. and analyzed. The results obtained were practically identical with those for urushic acid as will be seen by the following comparison:

$\begin{array}{rc}\text { FOUND } & \text { MEAN FOUND FOR } \\ \text { URUSHIC ACID } \\ \text { C.....77.07 } & 77.05 \\ \text { H....8.77 } & 9.01\end{array}$

He considers this as a polymerization product, a molecular transformation under the influence of strong hydrochloric acid and names it $\beta$-urushic acid, and states that it is soluble ${ }^{12}$ in the usual solvents for urushic acid. He claims that the substance obtained by the decomposition of an alkali salt of urushic with hydrochloric acid is the same body as $\beta_{\text {-urushic acid. }}$

By the action of strong nitric acid he obtained a sponge-like body which he washed with water, dissolved in alcohol, and precipitated with ferric chloride. The precipitate was washed, dried and analyzed with the following results:

$\begin{array}{rc}\text { FOUND } & \begin{array}{c}\text { CALCULATED FOR } \\ {\left[\mathrm{C}_{14} \mathrm{H}_{15}\left(\mathrm{NO}_{2}\right)_{2} \mathrm{O}_{2}\right]_{3} \mathrm{Fe} .}\end{array} \\ \mathrm{C} \ldots \ldots .4 \mathrm{I} .49 & 5 \mathrm{I} .59 \\ \mathrm{H} \ldots \ldots .82 & 4.6 \mathrm{I} \\ \mathrm{NO} \ldots .28 .16 & 28.25 \\ \mathrm{Fe} \ldots \ldots .97 & 9.8 \mathrm{I}\end{array}$

This nitro body was light yellow, and soluble in the usual solvents for urushic acid.

Yoshida oxidized urushic acid with strong chromic acid. The product was washed with water and then with absolute alcohol and dried at $105^{\circ} \mathrm{C}$. It was in the form of a brown powder which by analysis was found to contain one more atom of oxygen than urushic acid. See results below.

He heated a portion of the fresh juice on the water bath until the water was entirely removed, and at the same time the action of the enzyme was destroyed. This was then analyzed. For results see below.

Another portion of the lac was allowed to harden in the usual way by the action of the enzyme and then analyzed. For

${ }^{12}$ Doubtless this is a typographical error, and should read "insoluble in the usual solvents for urushic acid." 
convenience of comparison these results are tabulated, as follows :

\begin{tabular}{|c|c|c|c|}
\hline $\begin{array}{l}\text { Mean raw lac } \\
\text { dried by heat. }\end{array}$ & $\begin{array}{l}\text { Mean for lac hard- } \\
\text { ened by enzyme. }\end{array}$ & $\begin{array}{l}\text { Mean for urushic } \\
\text { acid oxidized by } \\
\text { chromic acid. }\end{array}$ & $\begin{array}{c}\text { Calculated for } \\
\mathrm{C}_{14} \mathrm{H}_{18} \mathrm{O}_{3}\end{array}$ \\
\hline 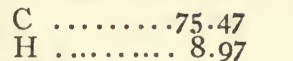 & $\begin{array}{r}70.85 \\
8.22\end{array}$ & $\begin{array}{r}71.52 \\
8.23\end{array}$ & $\begin{array}{r}71.79 \\
7.69\end{array}$ \\
\hline $\mathrm{N} \ldots \ldots \ldots$ o.II & 0.092 & $\ldots$ & $\ldots$ \\
\hline Ash $\ldots \ldots .0 .2 \mathrm{I}$ & 0.032 & $\ldots$ & $\ldots$ \\
\hline $0 \ldots \ldots \ldots 15.17$ & 20.52 & 20.25 & 20.52 \\
\hline
\end{tabular}

He concludes from the above analyses that the lac when hardened in the usual manner takes up one atom of oxygen for every molecule of urushic acid, becoming $\mathrm{C}_{14} \mathrm{H}_{18} \mathrm{O}_{3}$. This compound he names Oxyurushic acid.

More recently Bertrand ${ }^{13}$ has worked upon Japanese lac; however he has contributed nothing of importance to the knowledge of the alcohol soluble substance. His principal work was upon the soluble ferment referred to elsewhere.

EXPERIMENTAL, INVE,STIGAIIION.

Three samples of lac were used in the following experiments. The first and second were in glass jars bearing original Japanese labels. The third was in a tin can. Apparently all were identical.

The samples were all sent gratuitously to Prof. Tschirch. The first by forester Shirasawa, in Tokio, and others by the Rhus Company in Frankfort, a. M. to whom I here extend thanks.

When separated according to the method of Ishimatsu they gave the following results:

Parts soluble in alcohol......... $72.40 \%$

Parts soluble in water ........ 4. $4.05 \%$

Insoluble residue $\ldots \ldots \ldots \ldots \ldots \ldots 2.35 \%$

Water and volatile matter........21.20\%

I have found, as will appear later, that Yoshida's Urushic acid may be separated by benzin into

Benzin-soluble $\ldots \ldots \ldots \ldots \ldots \ldots \ldots . \ldots \ldots \%$

Benzin-insoluble .................. $2 \%$

and that the benzin soluble consists of three substances, one of which is a non-volatile poison, also that the gum and enzyme

1s Ann. chem. phys. ser. XII, I897, p. II5. 
(diastatic matter) cannot be separated, also that the lac contains acetic acid. The lac is of a grayish color. On exposure to air it rapidly darkens, but if undisturbed an impervious membrane soon forms on the surface thus preventing further change. The blackening of the lac is due to the action of oxydase or "Laccase," a soluble oxydizing enzyme, in the presence of moisture. The lac may also be darkened by other means, as, by the action of alkalies. For example, a piece of wood was coated with fresh lac; a second piece was coated with lac, sterilized by suspending a tube containing lac in boiling water for half an hour; and a third was coated with sterilized lac containing a small portion of potassium hydroxide; each piece of wood was covered with wet filter paper. The first rapidly changed to a dark brown color and in 24 hours the coating was black and hard. The second remained unchanged. The third immediately changed to black but remained moist for several days.

\section{LACRESINS, THE URUSHIC ACID OF YOSHIDA, THE LACCOL OF BERTRAND.}

It was desirous to separate the resinous portion from the gum and enzyme with the least exposure to the air, therefore the can containing lac was connected with a flask by means of a tube extending to the bottom of each. The flask was partially filled with alcohol and the lac drawn into the alcohol by suction. The contents of the flask were then agitated, filtered and the residue exhausted with alcohol. The alcoholic solution was strongly acid and had a peculiar aromatic odor which upon evaporation of the alcohol suggested the odor of acetic acid. The oily residue left after distillation of the alcohol was washed by shaking out with water. The watery solution was neutralized with potassium hydroxide and heated, when a fine black precipitate formed. This was removed by filtration and the filtrate evaporated to dryness. The residue with sulphuric acid gave an unmistakable odor of acetic acid, also when heated with sulphuric acid and alcohol the odor of acetic ether was developed. It also gave the cacodyl odor when heated with alkali and with arsenic trioxide. To prove that the presence of acetic acid was not due to the oxidation of the alcohol, a fresh portion of lac was extracted with ether, and the ether residue treated as above with the same results. It is therefore evident that the lac contains acetic 
in every way identical with oxyurushin. The alkaline solutions from which the oxyurushin was precipitated by acid, were evaporated and extracted with ether and alcohol but no organic substance was obtained.

SEPARATION BY LEAD ACETATE AND SUBACETATE.

Another part of the alcoholic residue, free from acetic acid, was redissolved in alcohol and an alcoholic solution of lead acetate added as long as it formed a precipitate. The precipitate which was of a light gray color was washed with alcohol, mixed with fresh alcohol, decomposed with sulphuric acid, and the excess of acid removed by shaking with lead carbonate. On evaporating the alcohol a thick dark brown oily residue was obtained. The residue was somewhat darker than the original alcoholic residue, but otherwise similar. To the filtrate secured from the lead acetate precipitate, lead subacetate was added as long as a precipitate formed. The precipitate was of a gray color, but a decidedly lighter gray than that obtained by lead acetate. On decomposing the precipitate, as above, an oily residue was obtained, which was also lighter in color than that obtained from the lead acetate residue.

The filtrate from the subacetate precipitate was still of a brownish color. The excess of lead was removed by adding a slight excess of sulphuric acid, and the excess of acid removed by shaking with lead carbonate and filtering. The filtrate was concentrated by evaporation and shaken out with ether. Upon evaporating the ether a residue was obtained which, when dissolved in alcohol, was readily precipitated by lead acetate or subacetate. By repeated experiments with the original alcoholic solution it was found that by precipitation with lead acetate and removing the lead and acid from the filtrate, reprecipitating and continually repeating this operation, that a series of oily residues could be obtained, gradually diminishing in quantity, and each increasing in fluidity, and becoming a shade lighter than the preceding. Only the last fractions were poisonous.

Lead subacetate is a better precipitant than the acetate. The acetic acid liberated evidently aids in preventing complete precipitation. The fact that the fractions decrease in color and viscosity, and that only the last were poisonous, indicates that the alcoholic extract consists of a mixture of two or more substances. 
But in no case can the above method be considered as a complete separation. In alcoholic solutions each fraction assumed a green or greenish black color with alkalies, the color varying with the concentration of the solution and the strength of the alkali used.

\section{SEPARATION OF THE LACRESINS BY SOLVENTS.}

SOLUBILITY OF THE ORIGINAL, ALCOHOLIC RESIDUE.

On first trial it appeared as though the alcoholic residue might be soluble in any of the ordinary solvents for oils and resins, but investigation proved that it was not completely soluble in carbon disulphide, methyl alcohol, amyl alcohol or petroleum benzin in all proportions.

After numerous experiments the following method of procedure was adopted. The alcoholic residue was dissolved in the proportion of I part to 7 of petroleum benzin, boiling point not over $60^{\circ} \mathrm{C}$., forming a clear solution, but further addition of benzin caused a precipitate. This was then poured into 55 parts of benzin which produced the immediate separation of a thick brown mass from which the still cloudy benzin was decanted. The brown deposit was dissolved in a small quantity of benzin and again separated by adding a larger amount. After this operation was repeated several times the deposit became entirely insoluble in benzin. It was then washed with benzin until the last washings were colorless. The washings were added' to the portions previously decanted and allowed to stand 12 hours-when the benzin became clear and was not affected by the further addition of benzin. The second deposit was dissolved, again precipitated by benzin and washed by agitation with benzin. The second deposit was thinner and lighter in color than the first.

By this method the alcoholic residue was separated into two distinct substances, a benzin-soluble, and a benzin-insoluble. The first and second deposit from benzin, while differing somewhat in physical appearance could not be said to consist of two distinct substances but doubtless consisted of mixtures of the same substances in varying proportions. Each was mixed with a small quantity of ether and added to methyl alcohol which immediately became cloudy and on standing a short time formed a deposit. The solution remained clear on the further addition of methyl alcohol. The residue was separated and washed with 
methyl alcohol but, as the washings remained turbid for several days, they were not added to the original solution.

The first benzin deposit contained more substance insoluble in methyl alcohol than the second deposit, otherwise no difference appeared, therefore their products were combined as methyl alcohol-soluble and methyl alcohol-insoluble substances. About half of the methyl alcohol-insoluble was soluble in ether, the remainder apparently having undergone some change during manipulation with the methyl alcohol. This theory is supported by the fact that the methyl alcoholic solution slowly deposits on standing. A similar condition was also observed when a portion of the original alcoholic residue was precipitated with petroleum benzin as a small portion of this also remained insoluble in ether. In fact all of the substances so far separated are evidently slowly oxidized, as all solutions except the petroleum benzin solution on standing for weeks form a slight insoluble deposit; and while the soluble benzin portion apparently remained unchanged, yet on largely diluting with benzin it again became cloudy; whereas previously it remained clear under similar conditions.

Three samples of the benzin soluble substance were placed in small colorless glass vials. No. I was corked and wrapped in black paper, No. 2 was merely corked and No. 3 was loosely closed with cotton. All were placed on a shelf exposed to strong light and allowed to remain for Io months. When they were tested as to their solubilities Nos. I and 2 dissolved readily in benzin but, on diluting with a large amount of benzin, became cloudy and upon standing, formed a slight deposit. That from No. I, being a little larger than from No. 2, would indicate that the reducing action of light has a tendency to prevent the change. No. 3 became quite thick but was still fluid. Only a small part was soluble in benzin.

SOLUBILITY OF THE SUBSTANCES SEPARATED FROM THE ALCOHOLIC RESIDUE.

The part soluble in benzin was also soluble in ether, chloroform, alcohol, methyl alcohol, amyl alcohol, carbon disulphide, toluol, oxylol, acetone, toluidin, pyridin, quinolin, carbon tetrachloride, amyl acetate, acetic ether, nitro benzol, turpentine oil, acetic acid and $80 \%$ solution of chloral hydrate. 
The part soluble in methyl alcohol was soluble in each of the above except benzin. The part insoluble in methyl alcohol but soluble in ether, was insoluble in benzol, toluol, oxylol, alcohol, amyl alcohol, carbon disulphide, turpentine, carbon tetrachloride, acetic acid and chloral hydrate solution.

The part insoluble in ether was also insoluble in any of the above solvents.

\section{SEPARATION OF' THE BENZIN-SOLUBLE PORTION.}

One volume of the substance was dissolved in eight volumes of benzin, four volumes of alcohol added and the. whole thoroughly agitated. Upon standing two layers appeared. The upper benzin layer was of a yellowish brown color, the lower reddish brown. These were separated and the benzin solution washed with alcohol as long as any thing could be removed. The benzin was driven off by evaporation leaving a non-poisonous, oily, brown residue, insoluble in alcohol.

The alcoholic solution was in turn washed by shaking out with benzin but with no positive result. The solution was next evaporated and a reddish brown, slightly gelatinous residue obtained. By rapidly washing this with a small quantity of benzin and evaporating a clear, light reddish brown residue was secured. Both of these residues proved to be poisonous. By continual washing with benzin or by employing it in larger quantities, the entire residue was dissolved. I believe that this residue consists of a poisonous and a non-poisonous substance but thus far the separation has not been secured. I hope to be able to separate them later.

All of the resins separated from the lac were tested for cholestrin but with negative results.

\section{CHEMICAL, REAC'TIONS.}

All of the substances separated gave precipitates with lead acetate, subacetate, silver nitrate, mercurous nitrate, cupric acetate and ferric chloride. The lead precipitates were of a light gray color gradually becoming darker on standing. The other precipitates were black. All were slowly blackened by the action of concentrated sulphuric acid. In the cold, concentrated nitric acid colored the benzin-soluble substance red which changed to brown on heating. The methyl alcohol-soluble substance was 
slightly darkened by cold nitric acid but became lighter on heating, forming a light spongy mass.

The benzin and methyl alcohol soluble substances were slightly darkened by strong hot hydrochloric acid, but by continual heating formed a spongy mass of a lighter color. All substances except the ether-insoluble were at first colored green, then black by strong alkalies. Various shades of green, and black were obtained, the shades varying with the concentration of the alkali and of the substance in alcohol or ether. Barium and calcium hydroxides produced the same effect though in a minor degree.

When heated with dry potassium hydroxide the substances furnished vapors that changed red litmus to blue, but gave no odor of ammonia. However the pyrrol reaction was obtained when a pine shaving was moistened with hydrochloric acid and held in the vapors. All of the above were tested for nitrogen by the Lassaigne test but with negative results ${ }^{14}$.

The pyrrol reaction was also obtained by boiling the substance with a strong solution of potassium hydroxide but the reaction was not as vigorous, and long-continued heat would be necessary to convert all the nitrogen into pyrrol. This is proven by the fact that the black precipitate still gave the pyrrol reaction, though formed by heating these substances with $5 \%$ potassium hydroxide for two hours on the steam bath.

\section{ANAI,YSIS OF SEPARATED CONSTITUENTS.}

The methyl alcohol soluble substance was spread on glass and placed in the drying oven. After several days it was sufficiently dry to be removed from the glass with a knife. The shavings were not brittle, but were cut into small pieces and returned to the oven where they remained for two weeks before they could be pulverized. The particles were hard and electric but by constant moistening with a mixture of alcohol and ether they were finally powdered. The powder was placed in a narrow tube and percolated with ether which dissolved a small amount. The ether was evaporated and the residue again spread on glass when in a few hours it became insoluble. This was doubtless part of the substance which had been prevented from drying by the surrounding particles. Some of the powder was ignited, after which a little ash was left. The remainder was

${ }^{24}$ See tests for Nitrogen under gums. 
repeatedly boiled with hydrochloric acid and washed with hot water but it was impossible to entirely remove the ash. When examined this was found to consist of silica, aluminum and traces of calcium. The powder was dried at a temperature of $105^{\circ}$ and analyzed, with the following result:

I $0.283 \mathrm{Gm}$. gave $0.2045 \mathrm{H}_{2} \mathrm{O}, 0.7452 \mathrm{Gm} . \mathrm{CO}_{2}$

II $0.3268 \mathrm{Gm}$. gave $0.2288 \mathrm{H}_{2} \mathrm{O}, 0.8457 \mathrm{Gm} \mathrm{CO}_{2}$

I $0.35 \mathrm{I} \mathrm{Gm}$. gave $5 \mathrm{Cc} . \mathrm{N}$ at $20^{\circ} \mathrm{C}$. and $7 \mathrm{I} 6 \mathrm{Mm}$.

II $0.4619 \mathrm{Gm}$. gave $6.9 \mathrm{Cc} . \mathrm{N}$ at $18.6^{\circ} \mathrm{C}$. and $716 \mathrm{Mm}$.

\begin{tabular}{lccc} 
& \multicolumn{1}{c}{ I } & II & Mean \\
C & 71808 per cent & $71.5 \mathrm{I}$ per cent & 71.659 \\
$\mathrm{H}$ & 8.01 per cent & 7.85 per cent & 7.93 \\
$\mathrm{~N}$ & 1.57 per cent & 1.646 jer cent & 1.608 \\
Asl & &
\end{tabular}

Another sample of the same substance was dissolved in alcohol, a solution of sodium hydroxide added in excess, and heated until the alcohol evaporated. The bulky black precipitate was washed until free from alkali, then boiled with hydrochloric acid which changed the color to a reddish brown. The precipitate was washed until free from acid, dried, powdered and analyzed with the following results:

I $0.2436 \mathrm{Gm}$. gave $0.1718 \mathrm{Gm} . \mathrm{H}_{2} \mathrm{O}, 0.64 \mathrm{II} \mathrm{Gm} . \mathrm{CO}_{2}$

II $0.222 \mathrm{Gm}$. gave $0.1534 \mathrm{Gm}$. $\mathrm{H}_{2} \mathrm{O}, 0.5^{814} \mathrm{Gm}$. $\mathrm{CO}_{2}$

I $0.2876 \mathrm{Gm}$. gave $1.5 \mathrm{Cc}$. $\mathrm{N}$ at $20^{\circ} \mathrm{C}$. and $711.5 \mathrm{Mm}$.

II $0.343 \mathrm{Gm}$. gave $2.0 \mathrm{Cc}$. $\mathrm{N}$ at $24.5^{\circ} \mathrm{C}$. and $7 \mathrm{I} 4 \mathrm{Mm}$. I

$\begin{array}{ll}\mathrm{C} & 71.72 \\ \mathrm{H} & 7.788 \\ \mathrm{~N} & 0.49 \\ \text { Ash } & 1.08\end{array}$

II

71.418

7.773

0.560

I.060
Mean

71.569

7.830

0.525

1.070

The substance insoluble in methyl alcohol and insoluble in ether was heated with hydrochloric acid for four hours to remove ash, but even that did not secure its complete removal. It was washed until free from acid, dried and analyzed with the accompanying results :

$0.388 \mathrm{Gm}$. gave $0.288 \mathrm{r} \mathrm{Gm} . \mathrm{H}_{2} \mathrm{O}, \mathrm{r} .0232 \mathrm{Gm} . \mathrm{CO}_{2}$

I $0.554 \mathrm{Gm}$. gave $8.4 \mathrm{Cc}$. $\mathrm{N}$ at $23^{\circ} \mathrm{C}$. and $714 \mathrm{Mm} .=1.6$ per ct $\}$ Mean r,68 II $0.457 \mathrm{Gm}$. gave $7.6 \mathrm{Cc}$. $\mathrm{N}$ at $25^{\circ} \mathrm{C}$, and $712 \mathrm{Mm} .=1.76$ per ct. $\}$ per cent

C 71.896

\begin{tabular}{l}
$\mathrm{H} \quad 8.303$ \\
\hline
\end{tabular}

$\mathrm{N} \quad 1.680$

Ash 0.400

The substance insoluble in methyl alcohol but soluble in ether was spread on glass, placed in the drying oven where it dried in a 
few hours. It was very hard to powder and was insoluble in all ordinary solvents. When analyzed it gave the following results:

$0.3606 \mathrm{Gm}$. gave $0.295 \mathrm{Gm} . \mathrm{H}_{2} \mathrm{O}, 0.97 \mathrm{I} \mathrm{Gm}$. $\mathrm{CO}_{2}$

$0.4104 \mathrm{Gm}$. gave $7.3 \mathrm{Cc}$. at $25^{\circ} \mathrm{C}$. $\mathrm{N}$ and $712 \mathrm{Mm}$.

$\begin{array}{ll}\mathrm{C} & 73.430 \\ \mathrm{H} & 9.145 \\ \mathrm{~N} & \mathrm{1} .850 \\ \text { Ash } & 0.45 \mathrm{I}\end{array}$

A second sample of the above was dissolved in ether and alcohol added, then precipitated with sodium hydrate, heated for two hours on the steam bath, washed until free from alkali, again heated for four hours with hydrochloric acid, washed and dried. Analysis gave the following result:

$0.2074 \mathrm{Gm}$. gave $0.194 \mathrm{Gm}$. $\mathrm{H}_{2} \mathrm{O}, 0.5482 \mathrm{Gm} \mathrm{CO}_{2}$

$0.2926 \mathrm{Gm}$. gave $2.2 \mathrm{Cc}$. $\mathrm{N}$ at $2 \mathrm{I}^{\circ} \mathrm{C}$. and $7 \mathrm{I} 2.5 \mathrm{Mm}$.

$\begin{array}{lr}\mathrm{C} & 72.08 \\ \mathrm{H} & 10.46 \\ \mathrm{~N} & 0.74 \\ \text { Ash } & \mathrm{x} .02\end{array}$

Part of the benzin-soluble substance was dissolved in alcohol, a strong solution of sodium hydroxide added and heat applied. An adhesive, black mass formed on the surface with a thick grayish-black mixture underneath. When cold, globules of an oily substance could be seen. An attempt was made to separate them but without success. Ether and benzin dissolved a large part of the precipitate together with the oily globules, forming an inseparable emulsion. More sodium hydroxide was added and the whole again heated for two hours, when a black precipitate separated leaving a clear solution. The solution was separated as completely as possible by decantation. Distilled water was added to the precipitate, when it again formed a homogeneous mixture as inseparable as before-but the addition of more alkali produced a separation. All attempts to free the precipitate from alkali by washing failed, as it invariably formed the same homogeneous mixture which could not be filtered and refused to separate on standing. However, the addition of sodium chloride to the mixture secured a perfect separation. The precipitate was carefully collected on a filter and washed with solution of sodium chloride until nearly free from alkali. It was then dried and heated with hydrochloric acid which changed the color to reddish brown. The precipitate was washed until free from acid, dried and powdered. The powder was exhausted with ether which 
dissolved about one-third. The insoluble part which continued obstinately insoluble in all ordinary solvents, was dried and analyzed. Result of analysis:

I $0.366 \mathrm{Gm}$. gave $0.2628 \mathrm{Gm} . \mathrm{H}_{2} \mathrm{O}, 0.945 \mathrm{Gm} . \mathrm{CO}_{2}$

II $0.3016 \mathrm{Gm}$. gave $0.213 \mathrm{Gm}$. $\mathrm{H}_{2} \mathrm{O}, 0.7855 \mathrm{Gm}, \mathrm{CO}_{2}$

I $0.3566 \mathrm{Gm}$. gave I Cc. $\mathrm{N}$ at $2 \mathrm{I}^{\circ} \mathrm{C}$. and $717 \mathrm{Mm}$.

II $0.3006 \mathrm{Gm}$. gave I Cc. $\mathrm{N}$ at $22^{\circ} \mathrm{C}$. and $719.5 \mathrm{Mm}$.

$\begin{array}{lccr} & \text { I } & \text { II } & \text { Mean } \\ \text { C } & 70.96 & 71.032 & 70.996 \\ \text { H } & 8.03 & 7.899 & 7.965 \\ \text { N } & 0.24 & 0.25 & 0.245 \\ \text { Ash } & & & \end{array}$

The ether solution was darker and more truly red than any of the other solutions; on allowing the ether to evaporate spontaneously and allowing the residue to stand for a few hours, a portion became insoluble in all ordinary solvents. This was exhausted with ether, dried and analyzed with the following results :

I $0.3104 \mathrm{Gm}$. gave $0.2387 \mathrm{Gm} . \mathrm{H}_{2} \mathrm{O}, 0.7983 \mathrm{Gm} . \mathrm{CO}_{2}$

II $0.2394 \mathrm{Gm}$. gave $0.19 \mathrm{Gm} . \mathrm{H}_{2} \mathrm{O}, 0.622 \mathrm{Gm} . \mathrm{CO}_{8}$

I $0.415 \mathrm{Gm}$. gave $3.2 \mathrm{Cc} . \mathrm{N}$ at $2 \mathrm{I}^{\circ}$ and $720 \mathrm{Mm}$.

$\begin{array}{lccc} & \text { I } & \text { II } & \text { Mean } \\ \text { C } & 71.012 & 70.897 & 70.954 \\ \text { H } & 8.596 & 8.877 & 8.736 \\ \text { N } & - & - & 0.850 \\ \text { Ash } & - & - & 0.210\end{array}$

The ether extract from above was allowed to evaporate spontaneously as before but remained soluble in ether and alcohol even after standing several days and after repeated solution and evaporation. On heating the residue at $100^{\circ}$ for a short time it became insoluble and behaved in all respects like the preceding. Analysis gave these results:

I $0.329 \mathrm{Gm}$. gave $0.250 \mathrm{Im} . \mathrm{H}_{2} \mathrm{O}, 0.8874 \mathrm{Gm} . \mathrm{CO}_{2}$

II $0.3374 \mathrm{Gm}$. gave $0.2588 \mathrm{Gm}$. $\mathrm{H}_{2} \mathrm{O}, 0.912 \mathrm{I} \mathrm{Gm} . \mathrm{CO}_{2}$

I $0.3946 \mathrm{Gm}$. gave $3.4 \mathrm{Cc}$. $\mathrm{N}$ at $22^{\circ} \mathrm{C}$. and $720 \mathrm{Mm}$.

$\begin{array}{lccc} & \text { I } & \text { II } & \text { Mean } \\ \mathrm{C} & 73.554 & 73.72 \mathrm{I} & 73.637 \\ \mathrm{H} & 8.503 & 8.579 & 8.541 \\ \mathrm{~N} & 0.940 & - & 0.940 \\ \text { Ash } & & & 0.160\end{array}$

H. Yoshida oxidized the alcoholic extract (Urushic acid) with chromic acid mixture, and obtained a brownish powder which he washed with alcohol, dried and analyzed. 
For comparison his results will be given with the means from the preceding results:

PART INSOL,UBLE, IN BENZIN BU'T SOL,UBLE IN METHYI, ALCOHOL.

\begin{tabular}{|c|c|c|c|c|c|}
\hline & & C & $\mathrm{H}$ & $\mathbf{N}$ & Ash \\
\hline $\mathbf{I}$ & Methyl alcohol soluble (dried) ......... & 71.659 & 7.930 & I. 608 & 0.600 \\
\hline 2 & Methyl alcohol soluble precip. by $\mathrm{NaOH}$. & 71.569 & 7.830 & 0.525 & I.070 \\
\hline
\end{tabular}

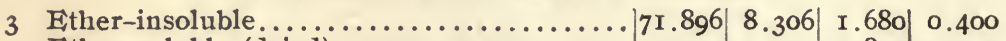

4 Ether-soluble (dried) .................. $73.430 \quad 9.145$ I .850 0.45 I

5 Ether-soluble precip. by $\mathrm{NaOH} \ldots \ldots \ldots \ldots .72 .080$ I0.460 0.740 ( 1.02

PART SOLUBLE IN BENZIN.

6 Benzin-soluble precip. by $\mathrm{NaOH}$ and insoluble in ether.......................70.996

7 Benzin-soluble precip. by $\mathrm{NaOH}$. soluble in

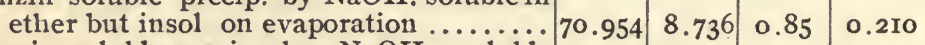

8 Benzin-soluble precip by $\mathrm{NaOH}$. soluble \begin{tabular}{ll|l|l|l|l|l|} 
in ether became insoluble with lieat..... & 73.637 & 8.541 & 0.94 & 0.160 \\
\hline
\end{tabular}

Yoshida's oxy-urushic acid ...........71.52 8.280

The methyl alcohol and ether soluble substances (Nos. 4 and 5) constitute less than one per cent of the original alcoholic residue, hence not enough material remained after other experiments for dulpicate analyses. Likewise only a small per cent of the alcoholic residue is represented by No. 8, that part of the benzinsoluble which, after treating with sodium hydroxide and hydrochloric acid, required heat to convert it into the insoluble form. These would have no practical effect upon the final product obtained by drying or oxidizing the lac. The substances from which the results in numbers $1,2,6$ and 7 were obtained form the principal part of the lac-resin that is soluble in alcohol.

Yoshida analyzed the dried lac and found $\mathrm{C} 70.85 \%$, H 8.22\%, N. 0.092, Ash 0.032.

The one quality which has made Japanese lac so valuable is its power to resist atmospheric action, solvents and chemicals. The preceding results show that strong chemicals, like alkalies and acids, convert the lac-resin into its insoluble form. Also that the final product appears to be the same whether obtained by the action of the enzyme, as in the usual method of hardening, or by chemical action. This becomes more apparent by comparison of the composition of this substance as obtained by various methods.

\begin{tabular}{|c|c|c|c|c|}
\hline & $\mathrm{C}$ & $\mathrm{H}$ & $\mathrm{N}$ & Ash \\
\hline Mean from Nos. I and 3 & 71.777 & 8.118 & 1.644 & 0.5 \\
\hline Mean of Nos. 2, 6 and 7 precip. by $\mathrm{NaOH}$. & 71.173 & 8.177 & 0.56 & 0.82 \\
\hline Action of chromic acid (Yoshida)...... & 71.52 & 8.280 & $\ldots$ & \\
\hline riginal lac hardened (Yoshida).. & 70.85 & 8.22 & 0.092 & 0.0 \\
\hline
\end{tabular}


Yoshida has named this substance oxy-urushic acid and given it the formula $\mathrm{C}_{14} \mathrm{H}_{18} \mathrm{O}_{3}$, but as it has none of the properties of an acid I have called it oxy-urushin. Owing to the presence of nitrogen I am loth to suggest a change in the formula. That nitrogen is present has been proved (beyond doubt) by the methods more fully given under gum-enzyme. That nitrogen is in actual combination is supported by the fact that it is separable only by fusing with dry fixed alkali, or incompletely by long boiling with a solution of fixed alkali. Owing to the small amount of nitrogen present, a very slight error in estimation would materially affect the results from calculation of a molecular formula.

The Kjeldahl method could not be used for the determination of the nitrogen, hence the necessity of using the Dumas method. The principal objection to this method is the difficulty of completely removing the air from the fine copper oxide. After numerous experiments the substance was finally mixed with copper oxide in fine powder and placed in a copper boat which was then placed in the combustion tube and the air removed by carbon dioxide, generated from sulphuric acid and potassium carbonate by Thiele's method ${ }^{15}$. The results were very concordant.

For calculation of the empirical formula only those results which were obtained without heating with alkali, can be used, as alkali causes a loss of nitrogen. Therefore the mean from I and 3 , corrected for ash, was used as follows:

\begin{tabular}{|c|c|c|}
\hline $\begin{array}{l}\text { Mean from } \\
I \text { and } 3:\end{array}$ & $\begin{array}{l}\text { Calculated for Ash } \\
\text { Free Substance }\end{array}$ & $\begin{array}{l}\text { Calculated for } \\
\mathrm{C}_{102} \mathrm{H}_{138} \mathrm{~N}_{2} \mathrm{O}_{19}\end{array}$ \\
\hline $\begin{array}{l}\text { C...7 } \\
H \\
H\end{array}$ & $\begin{array}{r}72.137 \\
8.156 \\
\end{array}$ & $\begin{array}{r}72.206 \\
8.202 \\
\end{array}$ \\
\hline $\begin{array}{ll}\text { N..... } & 1.644 \\
\text { Ash... } & 0.5\end{array}$ & $\begin{array}{l}1.652 \\
\ldots \ldots\end{array}$ & $\begin{array}{l}1.656 \\
\ldots \ldots\end{array}$ \\
\hline $0 \ldots \ldots \ldots$ & $\ldots \ldots$ & 17.936 \\
\hline
\end{tabular}

The above formula was calculated from the benzin-insoluble portion which represents only $22 \%$ of that portion of the lac that is soluble in alcohol. The remaining $78 \%$ which is soluble in benzin could not be obtained in a dry form, or changed into its end product without the use of reagents which caused a loss of nitrogen; hence no attempt was made to calculate a formula from the results obtained by combustion. The results obtained in 6,7 and 8 differ so much from those of 2 and 3 that it would

${ }^{15}$ Ann. der chen. 253, I889, p. 242. 
indicate a difference in composition, though the physical properties are the same.

It is evident that the urushic acid of Yoshida consists of at least four, if not five substances, differing in their solubilities as well as in other respects, for I have already shown that some dry in air to an insoluble substance, while others remain for months without drying; one is piosonous and the others not. However it is a remarkable fact that all may be converted into an end product having practically the same properties, resisting the action of all ordinary solvents, are black when heated with alkalies and red when heated with acids. The product seems to be the same whether obtained by drying with heat, by the action of the enzyme, or by the action of alkalies.

ORIGINAL, RESIDUE, INSOLUBLE IN AI,COHOL OR WATER.

The residue from the lac which was insoluble in alcohol or water consisted largely of hardened lac. By boiling this with caustic alkali a dark brown solution was obtained which, on neutralization and evaporation, left a hygroscopic residue, soluble in water but insoluble in alcohol or ether. All attempts to obtain a crystalline product failed.

The residue insoluble in alkali was dissolved by continued heating with fuming nitric acid, concentrated, and precipitated by pouring into water. The precipitate formed a gummy, plastic mass, soluble in alcohol but non-crystallizable.

The watery solution contained oxalic acid, but no picric or styphnic acid.

Oxyurushin when treated with fuming nitric acid gave the same results as above.

PREVIOUS INVESTIGATIONS OF SOLUBLE FERMENTS.

The first observation recorded upon the color action of Gums and of guaiac was made in I 809 by Goettling ${ }^{18}$ who observed a bluish-gray color when compounding a mixture of resin of guaiac, sugar, acacia, and peppermint water. In the same year Boulay ${ }^{17}$ observed the same color reaction when syrup, gum arabic and tr. of guaiac were mixed and by experiments proved that the color

${ }^{16}$ Bulletin de Pharmacie t. I. p. 220, 1809.

17 Bulletin de Pharmacie t. I. p. 225, 1809. 
was produced by the acacia and guaiac. He also records the fact that certain toothache remedies containing resin of guaiac colored the mouth blue or green, and, from experiments with albuminous substances, concluded that the color was produced by the albumen in the saliva and the guaiac.

Planche $^{18}$ in I8Io observed that pieces of certain fresh roots colored tr. of guaiac blue, also that nearly the same effect was produced by sulphurous acid gas and tr. guaiac.

In I8I9 Taddey ${ }^{19}$ observed that corn meal and powdered resin of guaiac when mixed with water and exposed to the air became blue.

Rudolphi ${ }^{10}$ found that in the above mixture the color was produced by gluten and guaiac.

Planche $^{20}$ in 1820 gives a list of about 25 plants, the fresh roots of which give a blue color with tincture of guaiac, and states that fresh milk not boiled produces the blue color with tr. guaiac. He was the first to discover that the power of albuminous substance to produce the blue color with tr. of guaiac was destroyed by heat. He experimented upon the action of light and air, successively examined and rejected the intervention of oxygen, but concluded that action was due to a kind of undetermined cyanogen.

Schönbein ${ }^{21}$ in 1856 observed that the juice of certain mushrooms, Boletus luridus and Agaricus sanguincus, colored tincture of guaiac blue but lost their power when heated to $100^{\circ} \mathrm{C}$. In $1868^{22}$, he reports that the blue color is formed by ozone, produced by a kind of catalytic action. He arrives at this conclusion after a series of experiments with the fresh juice from plants, and tincture of guaiac, under varying conditions of light and air, and with oxygen obtained from other sources.

In 1872 Struve $^{23}$ made some experiments upon the change of pyrogallol to purpurogalline by acacia, saliva and other substances which produced a blue color with tinct. of guaiac, but did not arrive at any definite conclusions as to the true action.

In 1877 Traube ${ }^{24}$ divided ferments into two groups: $a$. Oxi-

\footnotetext{
${ }_{18}$ Bulletin de Pharmacie t. II. p. 579, I8Io.

19 Journal de Fisice Chim. etc. 2d. Semestre, I8I9.

Journal de Pharmacie t. VI. 1820, pp. 16-25.

21 Jour. für Prakt. Chem. 67, 1856, 496.

22 Jour. für Prakt. Chem. I05, I868, p. I98.

${ }_{23}$ Ann. d. Chem. u. Pharm. 163, 1872, p. 160.

${ }^{24}$ Ber. d. Chem. Ges., I0, I877, p. 1985.
} 
dizing ferments, those that take up free oxygen and carry it to another substance. In this class he places the ferments that produce a blue color with tincture of guaiac, such as that found in potatoes and many other plants. $b$. Reducing ferments; those that have the power of changing the combined oxygen, producing not only an oxidation product but also a reduction product, as alcohol and carbonic acid from sugar, by the action of yeast.

In 1882 Clermont and Cheutard ${ }^{25}$ obtained a considerable quantity of pur-purgallin by exposing a solution of pyrogallol containing 10\% of acacia for several weeks to the action of airbut failed to recognize the true cause of the change in color.

In $1883 \mathrm{H}$. Yoshida ${ }^{26}$ was the first to discover that it was an enzyme that acted as an oxidizing agent. He proved that the milky juice of Rhus vernicifera was converted into a hard insoluble black varnish by the action of a peculiar diastatic substance contained in the juice and that the change took place in the presence of moisture, but more rapidly in moist oxygen. Also that the change did not take place at all in the presence of dry carbonic acid gas, or in a solution that had been previously boiled, thus proving that the color change was due to a distase which was destroyed by heat. He also proved that the substance acted upon by the enzyme had taken up oxygen, but did not give off carbonic acid.

Bouffard $^{2 \pi}$ states that the disease of wines which causes a skin to grow on the surface of the wine is due to an enzyme and that if the action is allowed to continue the wine becomes colorless or light yellow. Later ${ }^{28}$ he states that this action can be prevented by heating the wine to $60^{\circ}$ or by adding a very small quantity of sulphuric acid.

Gouirand $^{20}$ found that by filtering diseased wine through porous tile and precipitating the filtrate with alcohol he obtained a substance which, when added to sound wine, changed it rapidly to the diseased condition.

Martinand ${ }^{30}$ obtained a substance in ripe grapes, pears and

${ }^{25}$ Compt. rend. 97, 1882, p. 1254.

${ }^{26}$ Jour. Chem. Soc. 43,1883, p. 472.

${ }^{27}$ Compt. rend. I18, I894, p. 827.

${ }^{28}$ Compt. rend. 124, 1897, p. 706.

${ }^{29}$ Compt. rend. I20, I895, p. 887.

${ }^{39}$ Compt. rend. I21, 1895, p. 502. Also 124, 1897, p. 512. 
apples which gives the reactions of laccase but does not seem to be identical with it.

Cazeneuve $^{31}$ found that laccase produced only a very slight action in wines. He therefore attributed the disease to a particular enzyme and named it "Oenoxydase." He obtained it in the form of a gum by precipitating it from the wine by the addition of a large amount of alcohol. It colors guaiac blue, is active at $0^{\circ} \mathrm{C}$. and is not entirely destroyed at $65^{\circ} \mathrm{C}$. He finds that the coloring matter of wines is a phenol-like body which is oxidized by oenoxydase.

Laborde $^{32}$ attributes the secretion of Oenoxydase to a mould, Botrytis cinerea (sweet rot), which is present at the root of the vine.

Eduard Schär ${ }^{23}$ has especially examined the enzyme in Phytolacca decandra. He used an extract prepared by macerating the fresh parts of the plant in glycerin containing not more than 5 or I0\% of water, for a few days, then filtering. He states that an extract so prepared scarcely loses any of its activity for a year and a half. He found the extract from the leaves to be the most active, that from the root less active, and that from the flowers the least active.

Schär ${ }^{34}$ states that the blue color produced by enzymes upon tincture of guaiac depends upon the formation of a peculiar oxygen combination with the resinous constituent of guaiac, the guaiaconic acid. To the blue compound he gives the name ozonized-guaiaconic acid. He also states that guaiaconic acid is very sensitive to the action of acids, alkalies, light, air and water and, that when the tincture is to be used as a reagent, it should be prepared fresh, of the strength of 2 to 3 per cent. of resin free from wood.

The most valuable contributions regarding the action of soluble ferments have been given in a series of articles by G. Bertrand $^{23}$. He has given the name "Laccase" to the enzyme first found in Japanese lac by Yoshida but since found in many plants.

${ }^{31}$ Compt. rend. I24, I897, p. 406 and 78I.

${ }^{32}$ Compt. rend. 126, I898, p. 536.

${ }^{33}$ Vierteljahrsschrift d. Naturf. Ges. Zurich, XLI (I896) 233.

${ }^{34} 66$ Versammlung deutscher Naturforscher und Aertze \& Wien, 1904.

${ }^{35}$ Bull. Soc. 3d. Series to 51, p. 159, I891.

Compt. rend. II9, p. IOI2, 1894. 
Bertrand named the gummy substance that was separated from Japanese lac, "Laccase". He has since used a somewhat different method of separation in order to prepare it from other plants, like potatoes, turnips, beets, artichokes, asparagus, apples, pears, etc. The fresh parts of the plants are crushed, the juice expressed and after saturating with chloroform allowed to stand 24 hours when a coagulum forms and the juice is separated and the gum is then precipitated by alcohol.

Bourquelot and Bertrand ${ }^{36}$ examined about 200 species of mushrooms of which they give the following:

\begin{tabular}{|c|c|c|}
\hline EXAMINED & ACTIVE & INACTIVE \\
\hline Russule ... & 18 & 0 \\
\hline Lactarius $\ldots . . . \ldots \ldots \ldots \ldots . . . .20$ & 18 & 2 \\
\hline Psalliota $\ldots \ldots \ldots \ldots \ldots \ldots \ldots \ldots$ & 4 & I \\
\hline Boletus $\ldots \ldots \ldots \ldots \ldots \ldots \ldots \ldots$. & 10 & 8 \\
\hline Clitocybe $. . . \ldots \ldots \ldots \ldots \ldots . \ldots$ & 5 & 4 \\
\hline Marasmius $\ldots \ldots \ldots \ldots \ldots \ldots \ldots 6$ & 0 & 6 \\
\hline Cortinarius $\quad \ldots \ldots \ldots \ldots \ldots \ldots \ldots$. & I & I I \\
\hline Inocybe $\ldots \ldots \ldots \ldots \ldots \ldots \ldots \ldots$ & I & 5 \\
\hline Amanite $\quad \because \ldots \ldots \ldots \ldots \ldots \ldots \ldots$ & 2 & 5 \\
\hline Hygrophorius $\ldots \ldots \ldots \ldots \ldots \ldots 6$ & 0 & 6 \\
\hline
\end{tabular}

The parts of plants which contain the least chlorophyl contain the most laccase.

Bertrand ${ }^{37}$ has shown by experimenting upon such substances as hydroquinone, pyrogallol, gallic acid, etc., that the soluble ferments like laccase act by direct oxidation and that under its influence these bodies, in the presence of air, take up oxygen and give off carbon dioxide. He found that the phenols most easily acted upon are those having hydroxyl in the ortho or para position. When in the meta position they are oxidized with great difficulty.

On adding laccase to a solution of hydroquinone it changes to a deep red color and after some time green crystals are formed and the solution has the characteristic odor of quinone.

Bertrand $^{38}$ states that the darkening of certain substances as the dahlia, beet, etc., is due to the oxidation of tyrosin under the influence of soluble ferments. But that tyrosin resists indefinitely the action of gaseous oxygen in the presence of laccase. even in strong solutions ; therefore the blackening of the tyrosin

\footnotetext{
${ }^{36}$ Compt. rend. I21, p. $166 \&$ 783, 1895 .

${ }^{37}$ Compt. rend. I20, p. 226, 1895.

ss Compt. rend. I22, p. 1215, 1896.
} 
in the dahlia and beet is due to a peculiar oxidizer. This he has been able to separate and has called it "Tyrosinase". It exists not only in the dahlia and beet but in several varieties of mushrooms which do not contain tyrosin.

Tyrosinase is very unstable. It is best prepared from Russules.

One can either use juice of the mushrooms at once, or preserve them for future use by cutting in thin slices and drying in a vacuum. When wanted for use the dried residue is macerated for some time in cold water and then filtered.

If a solution of tyrosinase is mixed with a solution of tyrosin and the liquid frequently shaken to introduce air the liquid will first turn red, then black. Tyrosinase is not so frequently found in plants as laccase, but may be found in many fungi such as Russula, Lactarius, Hebeloma, Boletus, Amonita, and many others.

The two enzymes frequently exist in the same plants. Bertrand found that tyrosinase was more easily destroyed by heat than laccase.

Bertrand $^{39}$ gives the following as the theory of the action of oxydizing enzymes. That the manganese, which is present in all enzymes, even as high as $2 \%$, exists in the albuminous substance as a manganous compound, and plays the part of oxygen carrier. The oxygen molecule is broken by the manganous compound to form manganese dioxide and the remainder of the oxygen molecule acts upon the oxydizible body present. Finally through the acid character of the albumen radical, the manganese dioxide is decomposed and the original manganese compound restored. $\mathrm{He}$ believes that the activity of the enzyme is proportional to the manganese present.

Bourquelot ${ }^{t 0}$ reports upon the action of tyrosinase on phenols, etc. He states that the tyrosinase of mushrooms forms with guaiacol a red precipitate.

Bokorny $^{41}$ after giving the apparent similarity of enzymes and protoplasm, especially with reference to the action of light and temperature, concludes that one can scarcely think that they originate from the same source.

${ }^{39}$ Compt. rend. 124, 1356, 1897.

40 Repertoire de Pharmacie, 1897 , p. 136.

${ }^{41}$ Allgeminen Brauer und Hopfen Zeitung, No. 74, I90I. 
Loew ${ }^{42}$ reports two kinds of enzymes, an insoluble and a soluble form- $\alpha$ - and $\beta$-catalase respectively. The former is probably a compound of the soluble catalase with a nucleoproteid, while the soluble catalase is an albumose and can be liberated by the action of very dilute alkaline media upon the insoluble catalase. He has studied these enzymes with special reference to the tobacco plant.

Catalase does not color tincture of guaiac blue, but changes hydroquinone into quinone. Traces of acids increases its action while alkalies destroy it.

Chodat and $\mathrm{Bach}^{43}$ state that catalase is not a true enzyme like oxydase or peroxydase, as its function is only to decompose hydrogen peroxide.

Kastle and Shedd ${ }^{44}$ have shown that phenolphthalin is oxidized to phenolphthalein by oxidizing ferments and that it forms a very sensitive reagent for the presence of soluble enzymes. They have tested this reagent upon a number of enzymes from plants and on a few from animals. These results were compared with those obtained by tincture of guaiac and found to be practically identical, i. e., all those enzymes which gave a blue color with guaiac, gave a pink color with phenolphthalin, the colors in both cases increasing or decreasing with the activity of the enzyme.

In $1898^{45}$ Laborde proposed to measure the activity of enzymes by comparing the color produced by the enzyme when acting upon an alcoholic tincture of guaiac, with a standard color formed by adding 0.5 gramme of iodine to $20 \mathrm{cc}$. of the tincture of guaiac.

Alliot and Pozzi-Escot ${ }^{46}$ found it impossible to estimate oxydases colorometrically either by Laborde's guaiac method or by Kastle and Shed's phenolphthalein method.

Kastle and Shed found that the only enzyme obtained from animal source, which acted as an oxidizing enzyme was the human saliva.

About this time Cavazzani ${ }^{47}$ found a soluble oxidizing en-

${ }^{43}$ U. S. Dept. of Agriculture, Report No. 68, I90I.

43 Arch. Sci. phys. nat. (IV), 17, 1904, p. 477.

4 Am. Chem. Jour. 26, I901, p. 526.

45 Compt. rend. I26, I898, p. 536.

49 Ann. Chem. Anal. 7, I902, p. 210.

${ }^{4 t}$ Cent. Physiol. I4, I901, p. 473. 
zyme in the cerebro-spinal fluid of dogs and calves, and Vitali ${ }^{45}$ reported oxydase in pus, which he obtained by triturating the pus with glass, and then extracting with water, dilute acetic acid, or with equal parts of glycerin and water. It imparted a blue color to tincture of guaiac. This action was destroyed by hydrocyanic acid, chloroform, hydroquinone, pyrogallol, and hydroxylamine, but not by phenol, thymol or mercuric chloride.

$\operatorname{Gersard}^{49}$ found in the ink sac of the cuttle-fish laccase, tyrosinase and an oxidizing diastase which is more resistant to heat that laccase.

Kastle and Loevenhart ${ }^{50}$ while studying the action of oxidizing enzymes have established the fact that the organic peroxides like benzol, phthalyl and succinyl peroxides will color tincture of guaiac blue.

The same authors have very thoroughly studied the poisonous action of a variety of substances upon enzymes, and also the effect of the same substance upon organic peroxides, and find that those substances which destroyed the power of enzymes to color guaiac blue also prevented the coloration by organic peroxides.

They made many experiments with the juice from the potato which colored guaiac blue, and oxidized phenolphthalin, but the enzyme could not be precipitated by absolute alcohol as most enzymes. They arrive at the following conclusions:

"I. That oxygen is absolutely essential to the production of the guaiacum-bluing ferment of the potato.

"2. That this so-called oxidizing ferment is in all probability not a true ferment, but an organic peroxide.

"3. That the oxidation phenomena occurring in the plant, and probably in the animal organism also, can be satisfactorily explained upon the supposition that the readily autoxidizable substance which they contain is oxidized to the peroxide condition by molecular oxygen, and that the peroxides thus formed in turn give up part of their oxygen to other less oxidizable substances present in the cell. In other words, that the process of rendering oxygen active, by the living cell, is probably brought

43 L'Orosi, 24, rgor, p. 263, from Jour. Chem. Soc.4. ii, 672.

4) Compt. rend. 136, 1903, p. 631.

${ }^{* 0}$ Am. Chem. Jour. 26, 1901, p. 539. 
about in essentially the same way that is accomplished by phosphorus, benzaldehyde and other oxygen carriers."

Hunger $^{\text {s1 }}$ states that the guaiac reaction is interfered with by tannins, certain sugars, hydrogen sulphide, pyrogallol and other reducing agents.

Pozzi-Escot ${ }^{52}$ reports that when living tissues of animal or vegetable origin do not affect guaiac, but decompose hydrogen peroxide, that reductase must be looked for, which may be done by treating them, out of contact with air, with a solution of indigo, or litmus, or ferric ferricyanide and note if any reduction has taken place. They also liberate hydrogen sulphide from a mixture of sulphur and potassium fluoride, if protected from the air.

Bach and Chodat ${ }^{\mathrm{s}}$ find that oxydase is always accompanied by peroxydase, which they have found in about 25 plant families. The oxydase has the power of forming peroxides in the presence of free oxygen, which can be detected by the liberation of iodine from hydriodic acid. When parts of plants containing these enzymes are heated to $80^{\circ} \mathrm{C}$. the power to liberate iodine or color guaiac blue is destroyed. This is also true of the expressed juice. The power to liberate iodine disappears more quickly than that which colors guaiac. When the substance ceases to act it may be made active again by the addition of a small quantity of hydrogen peroxide.

$\mathrm{Bach}^{54}$ showed that a large number of substances when submitted to slow oxidation in the air, formed peroxides, and that the peroxide formed helped to continue the oxidation. In the blood the easily oxidizable substances first form peroxides and these aid in the oxidation of the more difficultly oxidisable bodies. The oxidation does not seem to be influenced by light.

Wender ${ }^{\text {s5 }}$ thought that the action of the oxydase in the living cell is to cause the oxygen of the aeroxydase to oxidize the easily oxidizable bodies so that intermediate bodies are formed, then these are again decomposed by the action of catalase. The free oxygen by the action of anaeroxydase (peroxides) becomes active and oxidizes difficultly oxidizable substances.

s1 Ber. d. Bot. Ges. 19, I901, p. 648.

62 Ann. Chem. anal. 7, 1902, 260.

${ }^{5} 3$ Ber. d. Chem. 35, ro02, p. 2466.

s4 Compt. rend. 124, I897, p. 951.

${ }^{55}$ Chem. Zeit. 26, p. 1217 \& I221, 1902. 
Chodat and $\mathrm{Bach}^{58}$ prepared peroxydase from cucumbers and horseradish but on account of the large amount of water in the former, they preferred to prepare it from the horseradish as the yield was much larger. Their method was to reduce it to as fine a condition as possible and allow it to stand for an hour to permit the glucoside-splitting enzyme to act, then to express the juice and precipitate with absolute alcohol. The precipitate was extracted with $40 \%$ alcohol, the alcoholic solution concentrated in a vacuum at $30^{\circ} \mathrm{C}$. and precipitated with absolute alcohol and dried in a vacuum.

The product is a yellowish gummy mass which in solution reduces Fehling's solution; however they claim that this is not due to the enzyme, for by repeated precipitation an enzyme may be obtained which will not reduce Fehling's solution. The purest peroxydase obtained from horseradish contained 6 per cent. of ash of which aluminum amounted to 0.8 to I.4 per cent. and manganese from 0.2 to 0.6 per cent. They found that the peroxydase from Russule and Lactarius was much more active than that from the horseradish or cucumber; on the other hand with hydrogen peroxide the activity was reversed. By heating a mixture of oxydase and peroxydase to $70^{\circ} \mathrm{C}$. the former is destroyed while the latter is only weakened but seems to regain its strength on standing ${ }^{67}$ but if subjected to a second heating its activity is destroyed completely. In alcoholic solution it is destroyed by boiling. Peroxydase does not possess the power to oxidize except in the presence of peroxides. The same authors state ${ }^{68}$ that peroxydase and catalase are present in nearly all parts of plant and animal bodies, and apparently are antagonistic, as the first is active with hydrogen peroxide while the other is destroyed by oxygen. They experimented upon a mixture of oxygenase, peroxydase and pyrogallol alone, and in the presence of catalase, and found that catalase had no effect upon the amount of oxygen absorbed. In another experiment catalase was mixed with oxygenase and peroxydase, and the mixture allowed to stand over night, then hydrogen peroxide was added and the amount of gas liberated was found to be the same as without the catalase. Hence

ss Ber. d. Chem. 36, I903, p. 600.

${ }^{57}$ Compare U. S. Dept. of Agric., Bull. No. 8, 17.

s4 Ber. d. Chem. 36, I903, p. 1756. 
they conclude that peroxydase and catalase can exist in the same plants without interfering with the functions of either. They also prove that catalase and reductase are not identical.

Kunz-Krause ${ }^{80}$ and Dr. Richard Fibras ${ }^{60}$ believe that one of the causes of the deposit in tinctures is due to the action of enzymes.

Bourquelot $^{\text {or }}$ studied the ferments which cause hydrolisis of the various polysaccharides, and finds that two and in some cases three ferments are required to completely hydrolise polysaccharides. In another paper, with Herissey ${ }^{62}$ he deals with the ferment of milk, almonds, peach and cherry laurel leaves and finds that emulsine as obtained from almonds, is a mixture of several ferments, emulsin, lactase and probably gentiobias, and frequently invertin. He concludes:

I. That lactase accompanies, emulsin in the different almonds of rosaceae.

2. That emulsin exists without laccase, as in Perquillus niger leaves. kaphis.

3. That lactase exists without emulsin, as in the yeast of

Chodat and $\mathrm{Bach}^{\text {6s }}$ review the researches of soluble ferments (oxydase) and give the following theory: The oxidizing ferments called oxydase, are bodies of a peroxide character, therefore they are organic peroxides which heat decomposes. Their action is accelerated by a second class of bodies which act as catalytics, and have the power to bring back the peroxides to their normal condition. They state that there is present in the living cell a diastase (peroxydase) which acts on hydrogen peroxide similar to ferrous sulphate, and with hydrogen peroxide produces a blue color with guaiac.

Chodat and Bach give the following characteristics for peroxydase :

If free from other enzymes, it does not liberate oxygen from

59 Pharm. Centralhalle, I902, No. 52.

¿ Pharm. Post, 35, 1902, p. 548.

1 Jour. d. Chim. et d. Pharm., I903.

Also Compt. rend. 136, p. 762, 1903.

${ }^{62}$ Jour. d. Chim. et d. Pharm., I903.

Also Compt. rend. Soc. Biol. 55, p. 219, 1903.

" Ber. d. Chem. 35, p. 1275, 1902.

is Ber. d. Chem. 37, p. 1342, I904. 
hydrogen peroxide as Catalase, or oxydize pyrogallol as Oxygenase; or liquefy starch paste, forming substances which deduce Fehling's solution, as Amylase; or invert cane sugar, as Invertase; or break up glucosides, as Emulsin; or digest coagulated albumen, as the Proteolytic enzymes.

Chodat and $\mathrm{Bach}^{\mathrm{es}}$ state that Bertrand found that, by fractional precipitation of laccase with alcohol, he obtained a substance poor in manganese and weak in oxidizing power, also a substance rich in manganese and strong in oxidizing action, but did not suspect that the decrease in power of oxidation was connected with the separation of peroxydase. Five years later fractional precipitation was brought forward as a method of separation of peroxydase from oxydase, by Aso.

The authors have used this method to obtain two end fractions, one with weak oxidizing power and the other without any oxidizing action. 'The first was practically insoluble in $40 \%$ alcohol while the other was soluble, and was active with hydrogen peroxide, and behaved as a true peroxydase. The weak oxidizing fraction which principally took the part of an oxygen carrier they designate as Oxygenase. They add that it is comparatively easy to prepare peroxydase free from oxygenase, but have not succeeded in preparing oxygenase free from peroxydase. A partial separation may be made by extracting a mixture of the two with 30 to 60 per cent. alcohol, or by dialysis with pure water when the peroxydase passes into the dialysate. ${ }^{67}$

In 1892 Tschirch $^{\text {es }}$ called attention to the fact that the difference between the color of black and green tea was due to fermentation. The black tea is prepared by allowing the fresh leaves to undergo partial fermentation at a relatively low temperature, while in the case of green tea the ferment is destroyed by heat.

$\mathrm{Aso}^{69}$ states that the color of black tea is produced by the action of oxydase on the tannin in the first stage of preparation, while in the green tea the ferment is destroyed.

Tschirch and Oesterle ${ }^{70}$ state that the formation of cola-red

es Ber. d. Chem. 36, 606, 1903.

6 Buli. Coll. Agric. Tokio, 5, 2, 1902, p. 233.

- Compare Engler and Wild, Ueber die sogenannte activirung des Sauerstoffs und über Superoxyd bildung. Ber. d. Chem. 30, I669, 1897.

"s Indische Heil-und Nutzpflanzen und deren Kultur, Berlin, I892.

6.3 Bull. Coll. Agric., Tokio, 4, p. 254, I901.

7) Anatom. Atlas d. Pharmacognosie, p. 350. 
in cola nuts is produced by fermentation, and that the nuts may be preserved colorless by heating to 65 degrees, or by immersing in boiling alcohol.

Tschirch ${ }^{71}$ observed that cinchona bark does not become colored, if the fresh branches are immersed in hot water before removing the bark.

The same author states that it is the action of oxydases upon the tannin group, which produces the strong red-brown products that he has grouped together as, cinchona-red, tannin-red, cinnamon-red, kino-red, colo-red, etc. ${ }^{22}$

Wender ${ }^{23}$ attributes the brown color of bread to the action of an enzyme, and adds that the brown color of many trees is due to the action of enzyme on the tannin.

Browne $^{i 4}$ found lipase in rice bran and tested its hydrolytic action on castor oil and upon the oil from rice bran.

$M{ }^{75}$ finds that lipase acts as a hydrolizer in the decomposition of esters but that the decomposition is not complete if only alcohol and acid are present. After a time the action is reversed and esters are formed from the acid and alcohol present.

Wender and Lewin ${ }^{76}$ state that the enzyme of grain which has a catalytic action is not increased during germination. Also that the diastatic action may be destroyed by carefully increasing the heat, without destroying the catalytic action. Also that the outer thin brown seed coat contains the strongest enzyme, and decreases in strength toward the center.

Bourquelot and Marchadier ${ }^{\pi}$ find that oxydase and peroxydase are active in 10\% alcohol, and that both are destroyed by hydrocyanic acid. With vanilla, peroxydase and hydrogen peroxide act the same as oxydase with air, and suggest that peroxydase consists of two enzymes, one hydroperoxydase which, in the presence of air, is capable of converting water into hydrogen peroxyde, or forming peroxides with certain substances, and the other an indirect oxydase, capable of clecomposing the peroxides with the liberation of oxygen.

71 Schweiz. Wochschr. für Pharm., No. I0, 1905.

72 Angew. Pflanzenanatomie, p. I27.

${ }^{73}$ Chem. Zeit., 26, p. 1217, I902.

${ }^{74}$ Jour. Am. Chem. Soc., 25, p. 950, 1903.

${ }^{75}$ Chem. Centr., I902, ii, I424, from Woch. Braü. I9, p. 588.

${ }^{\text {r }}$ Chem. Centr., I904, I, p. I530, from Oest. Chem. Zeit., 7, p. I73, 1904.

7 Compt. rend. I38, p. I432, I904. 
GUM AND ENZYME.

After extracting the lac with alcohol the residue was extracted with cold water and the gum-enzyme precipitated by pouring into strong alcohol. The precipitate was dissolved in a small quantity of water and reprecipitated with alcohol. By repeating the operation several times and finally washing with ether and drying in an exsiccator, it was obtained perfectly white and easily reduced to powder. In physical appearance it is similar to powdered acacia. When so prepared the gum-enzyme is very active, rapidly changing tincture of guaiac to a deep blue color. If an emulsion is made with the gum-enzyme, water and the separated resin, it soon changes from yellowish-white to black. A solution of gum-enzyme with naphtol formed a purplish blue color, and with guiacol a red color in half an hour but produced no effect upon a solution of vanillin in hydrochloric acid. If a solution of the gum-enzyme is boiled with water, it becomes entirely inactive.

\section{TESTS FOR NITROGEN.}

It is a generally conceded fact that all enzymes contain nitrogen. The Lassaigne test for the detection of nitrogen is undoubtedly considered the most reliable. It consists in heating the substance with metallic potassium or sodium and converting the cyanide so formed into Prussian blue. This test was applied to the gum-enzyme, but failed to detect the presence of nitrogen. According to Kehrer the Lassaigne test must be modified for certain pyrrol derivatives, ${ }^{78}$ and cannot be applied to diazocompounds. ${ }^{79}$ In view of the certainty of the presence of nitrogen and the general reputation of the test, it was repeatedly tried with various modifications. The gum-enzyme was previously mixed with dry sodium carbonate and carefully ignited. The rapidity of the heating was varied. In another experiment the substance was placed in a narrow tube closed at one, end, and the tube drawn out to contract the opening, small pieces of sodium were then introduced and the tube again contracted, thus:

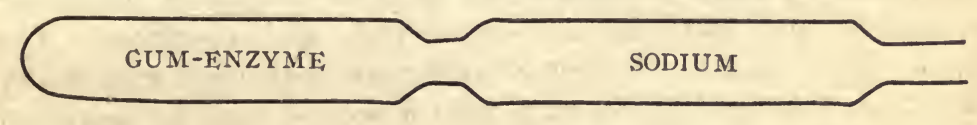

${ }^{78}$ Berichte, 35, 2,525; 1902.

70 Berichte, $17,1,178 ; 1884$. 
The sodium was first heated, then the gum-enzyme slowly heated so that the gases would pass over the glowing sodium. This test was repeated in the same manner, except that the gum-enzyme was first mixed with dry potassium hydroxide. In another experiment the substance was heated with a small quantity of concentrated sulphuric acid until a dry charred mass was obtained, then mixed with metallic iron and sodium and ignited, and finally tested for cyanide. In another experiment a modification of the Kjeldahl quantitative method was tried. The gum-enzyme was heated with concentrated sulphuric acid and a little mercuric oxide until a colorless solution was obtained. The solution was then mixed with an excess of potassium hydroxide and distilled. The distillate was passed through a tube containing a piece of red litmus paper into a mixture of chloroform, alcohol and potassium hydroxide to convert the ammonia into cyanide. The litmus paper remained red throughout the distillation. All attempts to convert the nitrogen into cyanide failed.

Another test for nitrogen which is considered less reliable than the Lassaigne test, is to convert the nitrogen into ammonia by heating the substance in a tube with soda-lime or potassium hydroxide. This test was applied to the gum-enzyme when the red litmus paper placed over the end of the tube rapidly changed to blue, but no odor of ammonia could be detected. The paper was evenly colored as if produced by some gaseous substance. The test was repeated with a pledget of cotton inserted in the tube below the paper to prevent the possibility of potassium hydroxide being mechanically carried to the litmus paper. The result was the same as in the previous test. A blank test was next made under exactly the same conditions, but with negative results. These experiments indicated the presence of a volatile base. Professor Tschirch thought the odor similar to pyrrol. I, therefore, repeated the test, placing in the top of the tube a pine shaving moistened with hydrochloric acid. This was rapidly colored red, thus strongly indicating, if not conclusively proving, the presence of pyrrol, or a pyrrol derivative. This was further confirmed by placing 5 grammes each of powdered potassium hydroxide and gum-enzyme in a flask and distilling. The vapors were passed through a condenser connected with a dry flask, and this again connected with a second flask by means of a tube which passed to the bottom of the flask, into a small quantity of water. At the end of the reaction the first flask contained 
a small quantity of colorless, strongly alkaline liquid, sparingly soluble in water, but readily soluble in alcohol and ether. The solution was tested with the following results:

On warming with hydrochloric acid and allowing to stand a short time a fine red precipitate separated. With sulphuric acid and quinone a green precipitate formed; with phosphomolydic acid, first a yellow, then a blue precipitate; with potassium ferrocyanide, dark green; with quinone alone, violet red. The contents of the second flask was also alkaline. The distillate was also tested by the Lassaigne test, but no Prussian blue obtained. As pyrrol gives the Lassaigne test it must be that the distillate did not consist of pyrrol, but was a pyrrol derivative.

Another evidence of the presence of nitrogen was obtained as follows: An ordinary open combustion tube was filled with copper oxide and ignited in a current of oxygen. After partially cooling, a platinum boat containing the gum was introduced and the gum burned in a current of oxygen. The products of combustion were conducted through potash bulbs containing a solution of potassium hydroxide, prepared from metallic potassium, and water distilled with potassium permanganate. Just before the combustion the solution was tested and found to be free from nitrogen compounds. After the combustion the solution was tested with diphenylamine when it gave the blue color characteristic of nitrates. With brucine and sulphuric acid a red color and with sulphuric acid and sulphate of iron the brown ring appeared.

This proves conclusively that the gum contained nitrogen in some form, which is converted into pyrrol, or a pyrrol derivative, by heating with potassium hydroxide.

\section{ATTEMPTS TO SEPARATE THE GUM FROM THE ENZYME.}

Hikorokuro Yoshida states that by removing his so-called urushic acid with alcohol and extracting the residue with cold water, and then boiling the solution, a white precipitate is formed. $\mathrm{He}$ assumes that it is the enzyme, but does not prove it, except that the solution was active before boiling and inactive afterwards, and that the precipitate contained nitrogen. It may have been an inactive vegetable albumen, although he states that it contained less nitrogen than these bodies usually contain. I have found, however, that a solution of the purified gum obtained by 
repeated precipitation with alcohol remained perfectly clear on boiling; yet, previous to boiling, the same solution was strongly active, rapidly changing tincture of guaiac to dark bluc, and the clear brown resin from the lac to a hard, black, insoluble substance.

Solutions of the gum were treated with acetic, hydrochloric, nitric and sulphuric acids of various strengths and with varying degrees of heat, but each failed to separate the nitrogenous substance from the gum. In one experiment the solution was boiled for half an hour with a dilute sulphuric acid, precipitated with alcohol, dissolved in water and reprecipitated with alcohol, washed until free from sulphuric acid, and dried in an exsiccator. This still gave the pyrrol reaction. Fractional precipitation was tried without apparent change in the relation of gum to nitrogen. Cold saturated solutions of magnesium sulphate, ammonium sulphate and sodium phosphate were tried in vain. Various modifications of Almen's solution of tannic acid were tried, but in no case was there any separation of nitrogenous from non-nitrogenous substance. Numerous precipitates were obtained, but in every case the precipitate contained both gum and nitrogen in apparently the same proportion as before. The dry powdered gum was heated for two hours at temperatures varying from $100^{\circ}$ to $160^{\circ} \mathrm{C}$. and tested both by boiling alone and with acids, but no separation occurred.

EXAMINATION OF O'THER GUMS FOR NI'TROGEN.

A number of the following samples were prepared by students and kindly furnished by Professor Tschirch from his collection. The remainder were prepared by the writer. In the case of the gum-resins the resin was removed by extracting with alcohol, the gum dissolved in water and precipitated by alcohol, purified by repeated precipitation and dried in an exsiccator. The acids were prepared by the same method, with the exception that the solutions were acidulated with hydrochloric acid each time before precipitation, and the precipitate finally washed with alcohol until free from hydrochloric acid. Nos. 14 and 15 were prepared by dissolving the tragacanth in a warm solution of sodium hydroxide, precipitating with alcohol and dissolving in water, and reprecipitating with acidulated alcohol.

Each sample prepared without heat was tested for enzyme, 
and all were tested by heating with potassium hydroxide and testing the vapor for alkalinity and by the pyrrol reaction. The enzyme's activity is indicated by the time required from the addi.. tion of the tincture of guaiac to the first appearance of color and afterwards to time required to produce a given shade. In each case o.I gramme of the gum was dissolved in $4 \mathrm{cc}$. of water and three drops of tincture of guaiac added.

\begin{tabular}{|c|c|c|c|c|c|}
\hline No. & GUM FROM & PREPARED BY & $\begin{array}{c}\text { PYRROL } \\
\text { REACTION }\end{array}$ & LITMUS & ENZYME \\
\hline I & Japanese Lac & \multirow{17}{*}{$\begin{array}{c}\text { Stevens } \\
\text { ". } \\
\text { ". } \\
\text { Oscar Halbey } \\
\text { " } \\
\text { Knitl } \\
\text { Dr. Saal } \\
\text { Bergmann } \\
\text { Stevens } \\
\text { Schereschewski } \\
\text { Stevens } \\
\text { " }\end{array}$} & \multirow{6}{*}{$\begin{array}{c}\text { Very strong } \\
\text { Weak } \\
\text { Medium } \\
\text { strong } \\
\text { ". }\end{array}$} & \multirow{3}{*}{$\begin{array}{c}\text { Blue } \\
\text { ": }\end{array}$} & \multirow{2}{*}{$\begin{array}{l}\text { Immediately } \\
30-60 \text { Minutes }\end{array}$} \\
\hline 2 & Ammoniac & & & & \\
\hline 3 & Ammoniac select & & & & 15.60 \\
\hline 4 & Acacia & & & & 8.13 \\
\hline $\begin{array}{l}4 \\
5\end{array}$ & Asafoetida & & & “ & I. 4 \\
\hline 6 & Asafoetida select & & & $" 4$ & I- 4 \\
\hline 7 & Olibanum_........... & & Weak & $"$ & $60-120$ \\
\hline 8 & Olibanum & & & " & $60-$ \\
\hline 9 & Opoponax & & “" & “" & 30- " " \\
\hline 10 & Tacamohaca & & Strong & “ & 30 Sec. 12 Min. \\
\hline II & Myrrh & & & “ & I5 Minutes \\
\hline 12 & Galbanum _. & & “ & “ & $15 \quad$ " \\
\hline 13 & Chicle_-nons & & Weak & $"$ & Inactive \\
\hline 14 & Tragacanth, white & & Medium & 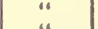 & \\
\hline 15 & Tragacanth, yellow & & $"$ & & $\ddot{4}$ \\
\hline 16 & Tragacanth, white & & “ & & \\
\hline & ACIDS PREPARED FROM & & & & \\
\hline 17 & Acacia _......... & Halbey & Medium & $\because$ & $" 4$ \\
\hline 18 & Opoponax & Knitl & Weak & $\because 6$ & $"$ \\
\hline 19 & Acacia & Stevens & Medium & “ & " \\
\hline 20 & Asafoetida_. & if & Strong & “ & “ \\
\hline 21 & Japanese lac & " & & “ & " \\
\hline
\end{tabular}

Nos. 8, 9, II and I2 did not become as dark as standard, even after standing twenty-four hours. Heat was used in the manufacture of No. I3, which would have destroyed the enzyme had it been present.

As the acids prepared from active gums did not give the enzyme reaction, it is evident that the hydrochloric acid used in their preparation destroyed the enzyme, but did not remove the nitrogen.

The enzyme in a solution of the gum from Japanese lac was rapidly destroyed by boiling, but the powder, after heating for two hours at $100^{\circ} \mathrm{C}$., was still more active than any of the other gums examined. The color with tincture of guaiac appeared at once and in five minutes became dark blue. Another sample, when heated for two hours at $120^{\circ} \mathrm{C}$., required ten minutes to produce the same deep blue shade. A third sample, heated for two hours at $140^{\circ} \mathrm{C}$., required ten minutes to produce any color, but became dark blue in thirty minutes. A fourth sample, after heating for two hours at $160^{\circ} \mathrm{C}$., was inactive. 
OXIDATION PRODUCTS.

The gum-enzyme was oxidized by heating I part of gum with 12 parts of nitric acid I.I5 sp. gr. on a water bath for one hour then evaporating to 2 parts and adding water 2 parts. After 24 hours the white crystalline deposit was washed with water and alcohol, and recrystallized from boiling water. The melting point was the same as for Mucic acid $210^{\circ} \mathrm{C}$. When analyzed:

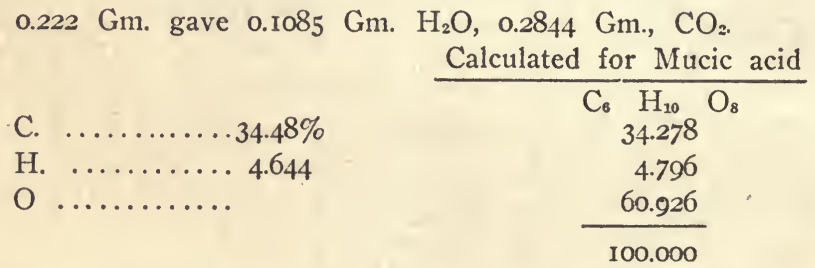

After removing the mucic acid with hot water from the first crystalline deposit, there remained a white powder insoluble in hot water, alcohol or acetic acid but soluble in hydrochloric acid. This was calcium oxalate which had been formed by the union of the calcium of the gum with the oxalic acid formed by oxidation. The mother liquor was evaporated to dryness, washed with ether, which on evaporation left well defined crystals of tartaric acid.

\section{HYDROLYSIS OF IACGUM.}

The gum-enzyme was heated with $2 \%$ sulphuric acid for 8 hours and the acid removed with barium hydroxide and carbonate. The solution was evaporated under diminished pressure, when it formed a very light yellow syrup, non-crystallizable, nonfermentable, reduced Fehling's solution and was dextrorotary. Alcohol dissolved only a small part of it. The remainder could be dissolved by using a large quantity of hot alcohol but deposited on cooling.

One part of the syrup was heated one hour with two parts of phenylhydrazine, 3 parts of sodium acetate, and 20 parts of water. On cooling an abundant yellow crystalline deposit formed. This was several times recrystallized from hot alcohol, when the M. P. remained constant beginning at $162^{\circ} \mathrm{C}$., and was complete at $164^{\circ}$ without liberation of gas. The crystals were in small spheroidal clusters, which under the microscope appeared to con- 
sist of aggregations of needles. This corresponds exactly with the description and melting point given for phenylsorbinosazone. ${ }^{80}$ A second crop of crystals was obtained by concentrating the mother liquor. These were somewhat darker than the first and had a M. P. of $157^{\circ} \mathrm{C}$., but with the production of gas. This corres. ponds with the description given for the osasone obtained from the inactive sorbin.

Furfurol was estimated from the gum according to Tollen's method $^{81}$ and calculated as pentosan but the results were not satisfactory. The method is designed for the estimation of furfurol in food products, and has very little value for scientific investigation.

An analysis of the gum-enzyme gave the following results:

I $0.2626 \mathrm{Gm}$. gave $0.1424 \mathrm{H}_{2} \mathrm{O}, 0.402 \mathrm{Gm} . \mathrm{CO}_{2}$.

II $0.3464 \mathrm{Gm}$. gave $0.1812 \mathrm{H}_{2} \mathrm{O}, 0.529 \mathrm{Gm} . \mathrm{CO}_{2}$.

I $0.35 \mathrm{Gm}$. gave 2 cc. $\mathrm{N}$ at $18^{\circ} \mathrm{C}$. \& $714.7 \mathrm{Mm}$.

II $0.45^{2} \mathrm{Gm}$. gave $2.3 \mathrm{cc} . \mathrm{N}$ at $16^{\circ} \mathrm{C}$. \& $713.7 \mathrm{Mm}$.

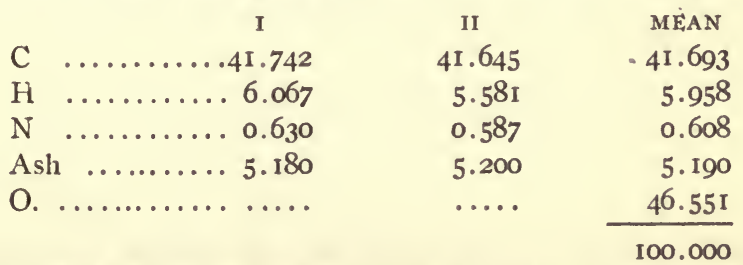

Bertrand $^{82}$ when working with soluble oxidizing ferments used the gum-enzyme from Japanese lac under the name "Laccase". He reports that it contained $0.44 \%$ of nitrogen which he determined by heating with soda-lime and estimating the ammonia formed by titrating with decinormal sulphuric acid. From this he calculated the amount of enzyme present by assuming that it has the elementary composition of albuminous substances.

He then gives the composition of the gum-enzyme as:

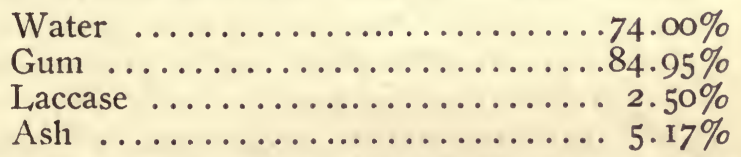

From the preceding work I think that I am justified in saying that what he estimated as ammonia was not ammonia, but pyrrol. 3, 304 .

${ }^{80}$ Vaubel Quantitative Bestimmung. Organ. Verbindungen II, Band

${ }^{21}$ Lunge. II Bd. 460.

${ }^{82}$ Bull. Soc. Chim. 3 series, 5I, p. 259, I89I. 
Before using zinc dust in some experinents upon the gum obtained from Japanese lac, I wished to be sure that it was free from nitrogen. I therefore subjected the zinc dust to the following tests, the results of which may be of interest to those who frequently use it in connection with organic substances:

When heated with potassium hydroxide it formed ammonia. When heated alone it also gave off ammonia. This led to the belief that nitrogen in some form had been absorbed from the atmosphere, and might be removed by heat. A small quantity was therefore placed in a loosely covered crucible, and strongly heated for half an hour. When cold it was tested for nitrogen by heating with potassium lydroxide. Its vapors rapidly changed litmus paper from red to blue. Upon the suggestion of Professor Tschirch a sample was thoroughly washed with water acidulated with hydrochloric acid, but this failed to completely remove the nitrogen.

As zinc dust is manufactured by heating zinc oxide with coal, it was believed that part of the nitrogen might consist of condensation products from the coal. Therefore a sample was placed in a long tube and percolated with ether. The ether when evaporated left a yellow, non-saponifiable oil, with an odor and fluorescence similar to petroleum. The oil, when heated with dry potassium hydroxide, gave off alkaline vapors, and the zinc in the percolator was still found to contain nitrogen. The greater portion of the oil appeared to be removed with the first portion of ether, but after continued percolation the ether left a residue upon evaporation, and it was evident that a much larger amount of ether was necessary for complete exhaustion ; therefore a smaller sample, from a can of zine dust which had been in the laboratory for more than ten years, was treated with ether in the same manner, and the powder tested from time to time. After using a large amount of ether the zinc was practically free from nitrogen, yet by taking a large amount of the zinc and heating with potassium hydroxide in a tube partially closed at the top so that all of the vapors came in contact with the litmus paper, the color was slightly changed, thus showing a mere trace of nitrogen. This sample was then allowed to stand in an open flask for a few days when it gave a decided ammonia reaction, thus showing that zinc dust rapidly absorbs nitrogen from the air. 
The fact that only a portion of the nitrogen in zinc dust is removed by heat indicates that the nitrogen is present in more than one form. This theory is also supported by the following experiments :

A fresh sample of zinc dust was washed with water ,the washings giving a decided ammonia test. The washing was continued as long as traces of nitrogen could be detected in the washings. It was then treated in the same manner with very dilute hydrochloric acid. By adding potassium hydroxide in excess to the acid solution and allowing to stand a few minutes until the precipitate settled, decanting the clear solution and boiling, the vapors gave the odor of ammonia and rapidly changed litmus from red to blue. Washing with acid was continued until the washings no longer gave a test for nitrogen. The zinc was then washed with water until free from acid, and rapidly dried in a drying oven, and at once extracted with ether, the ether evaporated and tested for nitrogen as above. Nitrogen was found to be present, though not in as large amounts as in the oil from the first sample examined, which was, however, directly treated with ether.

Three samples were examined: one from a large closely covered can which had been in use in the laboratory as above stated; another from a glass bottle which had been in the museum about fifteen years, and a third which was ordered by Professor Oesterle for these experiments. Practically the only difference found in the three samples was that the oil from the fresh sample was decidedly yellow, while that from the laboratory sample was somewhat lighter, and that from the museum sample was colorless.

Dr. Victor Steger ("Metalldämpfe in Zinkhütten," Chemischer und Chemischtechnischer Vorträge) gives the results of several analyses of zinc dust, some of which contain considerable insoluble residue consisting principally of carbon. To determine to what extent this was present, a large amount of zinc dust was treated with hydrochloric acid. At first the reaction was rapid, but after a time ceașed. The solution was decanted and fresh acid added, but as the reaction was very weak the mixture was heated. Even then a large amount remained undissolved. A few drops of copper sulphate solution were added and digested for several days, but a large amount remained insoluble. This was washed with water until free from acid, dried, and per- 
colated thoroughly with ether, which upon evaporation left a colorless oil. Upon removing the ether the zinc dissolved without difficulty in hydrochloric acid, conclusively proving that this sample contained no carbon, and that the insolubility was due to the presence of the oil.

\section{LAC POISONING.}

Goertz $^{\mathrm{s} 3}$ gives the following description of lac poisoning in which the idiosyncrasy of the individual plays an important part. A few hours after the poisoning the patient complains of an unpleasant tension of the skin, usually of the face, head and extremities. Soon after there forms an oedema of the affected parts. Small red points become visible, which look like fine rash. These grow larger forming on the points small blisters containing a watery fluid. The parts of the skin affected are restricted to the head and extremities.

Ishimatsu states : "It gives off a certain kind of volatile acid, poisonous in its property, and some persons are seriously attacked by it, producing great swellings on the face especially, and even the whole body where the acid comes in contact. During my examination in the laboratory, one day one of the apparatus-keepers came in and was violently attacked by it, producing ugly swellings all over his face. He told me at the time that it was exceedingly itchy, and by using solution of acetate of lead, chloride of potash and carbonate of soda, was said to have recovered from his suffering within a week."

"The poison that is evolved from urushi acts only on certain persons. I had to work with it for many days, yet never had any attack of the kind nor felt any uneasiness by it."

Prof. J. J. Rein ${ }^{85}$ describes the lac poisoning as follows:

"It is a peculiar, not very painful, and not at all fatal, but always very disagreeable disease, always attacking one new to the work, whether he be lac tapster, dealer, or lacquerer. It appears in a mild reddening and swelling of the back of the hands, the eylids, ears, the region of the navel and lower parts of the body, especially the scrotum. In all these parts great heat

${ }^{83}$ Ueber in Japan vorkommende Fish- und Lackvergiftungen. St. Petersburger medicinische Wochenschrift, I878, No. I2.

\&4 Manchester Literary and Philos. Soc., 3 Ser. 7, p. 254.

${ }^{85}$ The Industries of Japan, p. 349. 


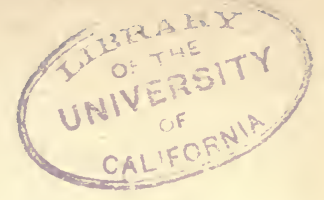

is felt and violent itching and burning, causing many sleepless nights. In two or three days the crisis is reached, and the swelling immediately subsides. In severe cases, small festering boils form also. This lacquer disease is not only caused by handling of the lac, but by its evaporation chiefly, especially that of the sharp Se-shime, to which I owe my own illness."

"The poison, however, is a volatile substance, and has nothing to do with the lac-acid and its higher oxidation, as Korschelt believed. If the poisonous property disappears in the drying of the plant, this amounts to nothing save that the volatile poison fully escapes in this manner. A considerable part of it is driven off in the preparation of the several kinds of lacquer, and by stirring in open vessels. For this reason, the lacquers mixed with colors are regarded far less dangerous than the raw lac and its direct derivatives."

Forne $^{88}$ compares the above symptoms with those of poisoning by poison ivy and anarcardium, as well as the cases of poisoning of the laborers in the vanilla depot of Bordeaux ${ }^{87}$ where nearly all, even from the first day, experienced strong itching accompanied with a burning sensation, especially on the face and hands. He finds a remarkable similarity in all of these cases and believes that he is justified in assuming that all are produced by cardol. He also states that anacardium is used in the preparation of Japanese lac, but I have been unable to find confirmation of this fact.

Dr. Andreas ${ }^{88}$ reports the case of a gardener in the botanical garden at Vienna, who was poisoned while collecting and transplanting Rhus vernicifera. On the same day the face became red, the skin inflamed, the eyelids, nose and cheeks swollen. The reddening extended to the neck, breast, hands and forearms. The genitals were also red and swollen. By dusting with starch the inflammation disappeared in fourteen days.

When opening the cans care must be exercised to prevent the vapors accumulated in the top of the can from coming in contact with the face or hands, as the poisonous part of the lac is volatile and may be removed by heating or by distillation. Yoshida also states that the lac contains a volatile poison which is dissolved with the urushic acid by alcohol but is almost completely driven

\footnotetext{
so Archiv. für Dermatologie und Syphilis, LX, p. 249.

${ }^{87}$ Revue d'Hygiene, Paris, 1883, p. 718.

88 Therap. Monotshifte, I903, p. I65.
} 
off by drying the acid at $105^{\circ}$ to $110^{\circ} \mathrm{C}$. Bertrand ${ }^{80}$ says that the lac must be handled with the greatest precaution because the least traces in the state of vapor produce on the face, hands and arms an intense rubrefaction accompanied by intense itching, and adds that these malicious properties make the study of lac very unpleasant, and he was obliged to interrupt his studies on account of individual sensibilities.

With these statements before me it was not without misgivings that I undertook the study of lac, and these were not allayed by my first experience. The first sample received was in a glass can with metal top which had become sealed by the lac, and was difficult to remove, but when finally started was accompanied by a slight sound of escaping gas. In about thirtysix hours an inflamed spot about $2 \mathrm{~cm}$. by $5 \mathrm{~cm}$. appeared on my wrist; it itched intensely for about a week and then disappeared. Laboring under the supposition that I was dealing with a volatile poison, I was extremely cautious not to come in contact with the vapors in any form, but supposed that I was practically safe after the alcohol had been distilled and the residue had been heated for some time. While shaking out an ether solution of the alcoholic residue with sodium carbonate solution, it was difficult to keep the hands entirely free from the solution and no especial pains were taken to remove it except to carefully wash with soap and water. However, after working some time with it my face began to swell and continued until ny eyes were nearly closed. It extended over hands, arms and limbs to the knees; the desire to scratch was very great so that it was almost impossible to sleep. This was also true of the face and ears to some extent. but here the sensation was more that of burning. After about a week the face became normal and I was able to resume my work but the limbs continued to itch and remained covered with a fine rash. After several weeks I became convinced that the underwear had absorbed some of the poison and though frequently washed still retained it. Soft gauze underwear was then worn next the skin, when the flesh soon became normal.

Various remedies were tried, such as, ointment of zinc oxide; a mixture of oxide of zinc, bismuth subnitrate, starch and solution lead subacetate, tincture of iodine with glycerin; solution of potassium permanganate; solution of oxalic acid. None

${ }^{89}$ Annales de Chimie et de Phyșique, Series XII, I897. 
of these seemed to give anything more than a temporary relief. The best results were obtained by rubbing the surface with a littlepetrolatum and then scraping it off with a knife and washing the surface with a weak solution of sodium hydroxide or carbonate. The burning on the face was relieved by keeping it moistened with a saturated solution of boric acid.

Dr. Jadassohn, Professor of Skin Diseases in the University of Bern, stated that the above symptoms did not prove that the poisonous principle was volatile, and kindly volunteered to make the physiological tests for me in order to determine whether the poisonous principle is volatile or not. He found that the rabbit was very sensitive to the poison. The method of testing was to rub a small quantity of the substance on the inside of the ear for 2 or 3 minutes. If poisonous, inflammation appeared in from I to 5 days and the surface soon became covered with watery blisters followed, in severe cases by necrosis of the superficial layers of the skin. This condition lasted about 14 days when it gradially disappeared.

The following are the most important results obtained from the tests:

I. Sterilized lac, prepared by suspending a iube of the lac in boiling water for half an hour, was poisonous.

2. An alcoholic solution of the lac was distilled and the distillate tested but was not poisonous.

3. After the alcohol was removed, the distillation was continued when a sinall quantity of aqueous distillate was obtained, but this was also inactive.

4. The residue in the retort was extremely poisonous.

5. A fresh can of lac was thoroughly cooled to prevent the escape of gas while opening, two small openings made, and tubes introduced. A small quantity of absorbent cotton was placed in the tube, used for the exit of vapor, to prevent particles of the fluid from being forced through. The vapor was then slowly forced out of the can upon the ear of a rabbit. Part of the ear had previously been moistened. The vapor was entirely without action. Since then I have worked over the lac, while evaporating it under all conditions without the slightest inconvenience.

6. The alcoholic residue was later separated into two parts, one soluble and the other insoluble in benzin. The first was 
poisonous and the second non-poisonous. A thin layer of the first was left in an open crystallizing jar for four months when it was found to be still poisonous.

Another sample of five grams was left in an open vial on a laboratory shelf for ten months, including the hot summer months. This was then tested on my arm and was found to be still active. These facts are sufficient to prove that the poisonous principle is non-volatile. Doubtless the cases of poisoning that have occurred from opening retainers have been due to minute particles of the lac being forced out with the vapor.

The poison is extremely active even in minute quantities and, as it forms a part of the resinous body, it is very difficult to remove from the skin or clothing. Washing with soap and water is not sufficient to insure its removal. If the hands after contact with the lac are thoroughly washed with soap and water until they are to all appearances clean, and then wet with a solution of caustic alkali, black spots will appear wherever the lac has been in contact. A mixture of powdered soap, pumice stone and sodium carbonate gives the best result. However, to insure safety I have usually followed this with soap and sand. The poison seems to have little or no effect upon the thick skin on the inside of the hand, but, to prevent its transmission to other parts, it should be removed as soon as possible. For example, by accident some of the benzin solution was thrown into one eye and over one hand. The eye was thoroughly washed with benzin and alcohol, but in my anxiety for the eye, the hand was forgotten for twenty or thirty minutes, when it was thoroughly washed with benzin and alcohol followed by soap and sand. The eye escaped without further inconvenience than that caused by the benzin, but in thirty-six hours the surface of the hand became slightly swollen, itched considerably for a week and then appeared to be covered with a thin dry scale, which finally disappeared. Since then I have tested different parts of the substance to determine whether or not they were poisonous, by cutting a hole $6 \mathrm{~mm}$. in diameter in a piece of gum paper, pasting this on the arm and applying the substance to the opening. In from thirty minutes to one hour the paper was removed and the spot washed with ether or benzin. When the substance was poisonous the spot became red and began to itch within 30 hours. From three to five vescicles usually appeared. The itching was not intense, 
usually lasting only a few minutes at a time. A dry scale formed over the surface and remained for several weeks after all irritation ceased.

In no case did the poisonous action extend beyond the surface to which it was applied, thus proving that the action is entirely local. If the surface, which has been in contact with the poison, is not thoroughly washed with some solvent like alcohol, benzin, ether or kerosene, the poison will be transmitted to other parts of the body As all kinds of fats and oils are solvents for the poison they should not be used as remedies. Should pustules form, the surface should be frequently washed to prevent the serum from being conveyed to other parts, as it is quite possible that it may be active. Experiments to determine this fact will be conducted in the near future.

The poison has not at the present time been isolated in a pure condition.

Dr. Jadassohn and his assistants, Drs. Winckler and Schulz, made 26 tests with parts of the lac obtained under different conditions.

Only that portion which is completely soluble in benzin is poisonous, and this, we have previously seen, was separated by shaking out the benzin solution with alcohol, into two parts, one soluble in alcohol and poisonous, the other insoluble in alcohol but soluble in benzin and non-poisonous. I have elsewhere stated that by fractional precipitation with lead acetate a partial separation of the poison was obtained, but that I did not consider it a practical method.

After the above experiments with the poison were made I received from Dr. F. Pfaff a reprint of his article "On the Active Principle of Rhus Toxicodendron and Rhus Venenata." As the poisonous action of these plants is practically identical with that of Rhus vernicifera, his work is of special interest in this connection. He has conclusively proved that the poisonous principle of poison ivy is non-volatile, thus shisttering the false idea that has existed for so many years. He claims to have separated the poisonous principle in a pure form by fractional precipitation with lead acetate as an oil. Dr. Pfaff gives the composition of his lead compound as $\mathrm{C}_{21} \mathrm{H}_{30} \mathrm{O}_{4} \mathrm{~Pb}_{6}$ and proposes the name "ToxI897.

90 -The Journal of Experimental Medicine, Vol. II, No. 2, p. I8I, 
icodendrol" as the name of the poisonous principle. The poisonous principle of Japanese lac is so intimately associated with the resin of the lac that $I$ have not considered the method of fractional precipitation to be a complete separation. Preceding investigations indicate that the poisonous principles of these plants are identical but further investigation is necessary before this can be accepted as conclusive. I hope during the coming year to be able to separate the poison from both these plants and to determine their relation.

The present researches in Japanese Lac were undertaken in the Laboratory of the Pharmaceutical Institute of Bern under the guidance of my most highly esteemed director, Professor A. Tschirch. To him and also to Professor Oesterle I desire to express my warmest and sincerest thanks for the inspiration and the friendly interest and advice which has ever been so freely and so kindly given.

I am also thankful to Dr. Jadassohn and his assistants, Drs. Winckler and Schulz for the physiological tests which they so kindly made.

The lac for this investigation was kindly presented by forester Shirasawa of Tokio, Japan, and the Rhus Company, Frankfort, Germany. To them I extend sincere thanks.

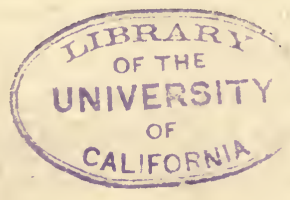






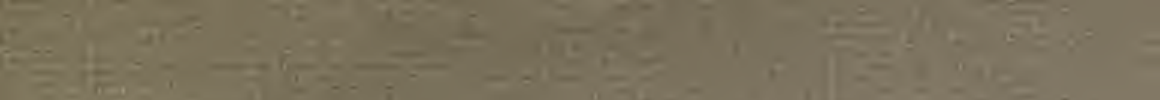

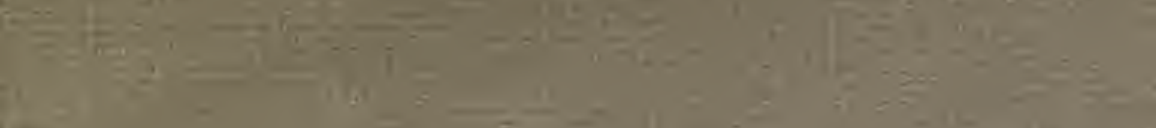

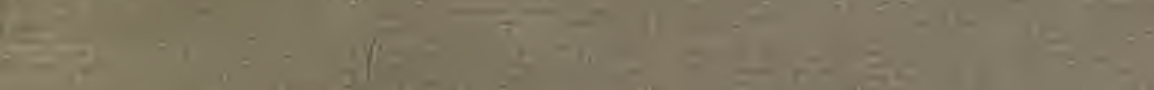

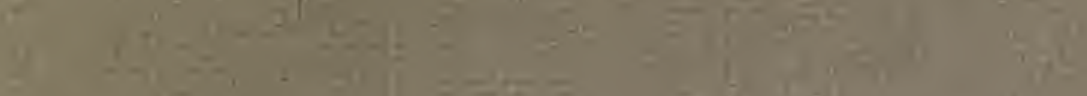

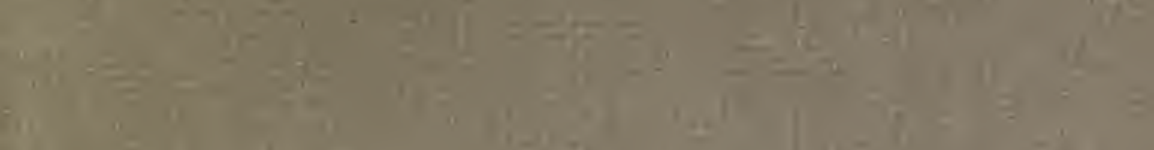

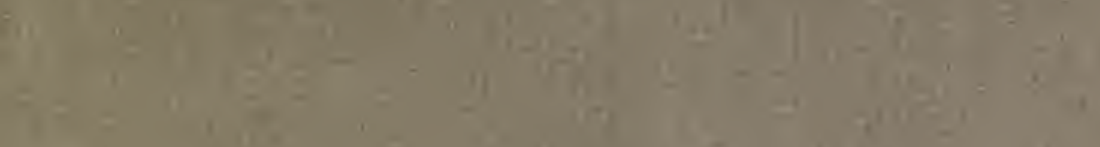

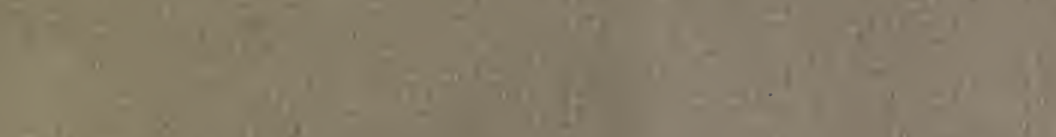

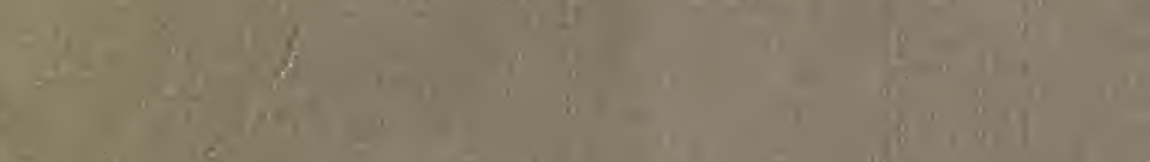

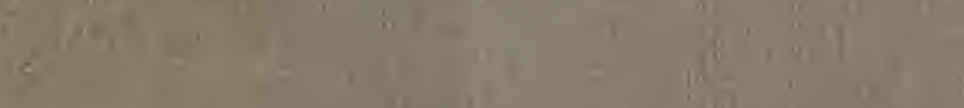

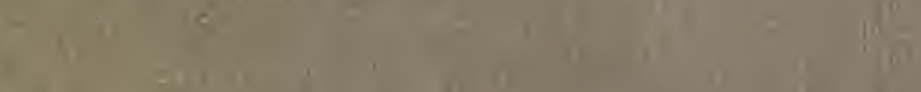
.

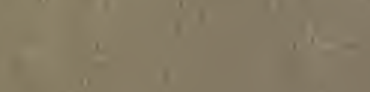
.

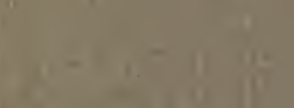

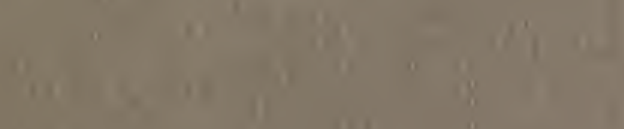

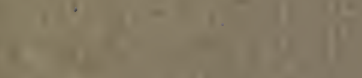

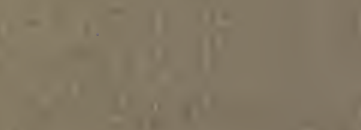

$4+$

if

.

$x_{x} x^{2}=$ $x^{2}-3 y=$

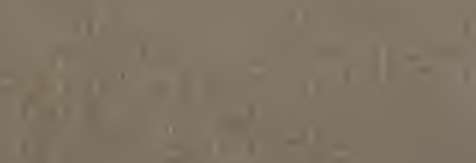

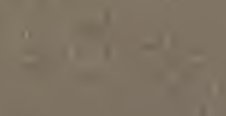

itis

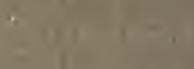
$=$

ing

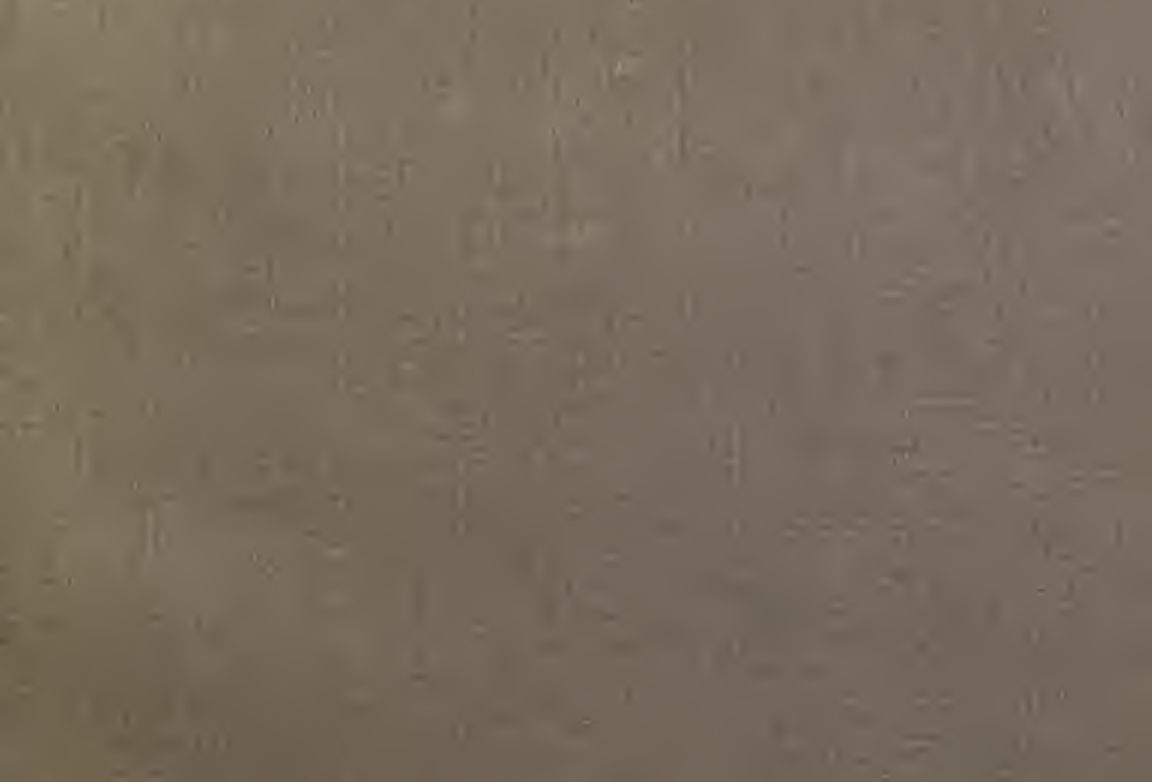


RETURN TO the circulation desk of any University of California Library

or to the

NORTHERN REGIONAL LIBRARY FACILITY

Bldg. 400, Richmond Field Station

University of California

Richmond, CA 94804-4698

ALL BOOKS MAY BE RECALLED AFTER 7 DAYS

- 2-month loans may be renewed by calling (510) 642-6753

- 1-year loans may be recharged by bringing books to NRLF

- Renewals and recharges may be made 4 days prior to due date.

DUE AS STAMPED BELOW

\section{OCT $28 \% 998$}

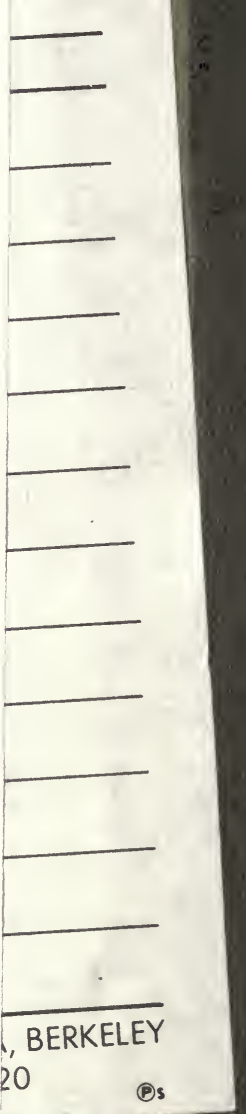




\section{YC 13752}

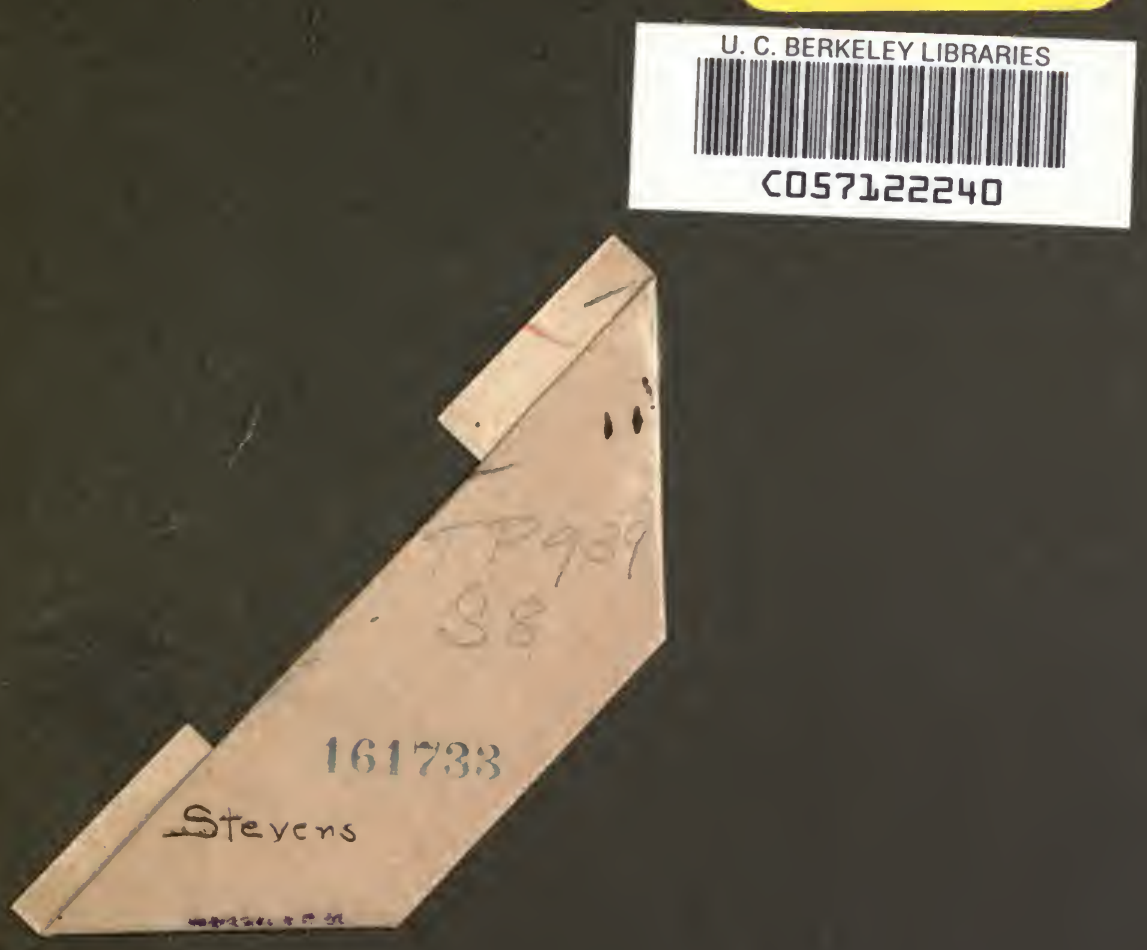


